\title{
Understanding the Growth of the Cellulosic Ethanol Industry
}

\section{Technical Report} NREL/TP-150-42120

April 2008

D. Sandor and R. Wallace

National Renewable Energy Laboratory

S. Peterson

The Peterson Group

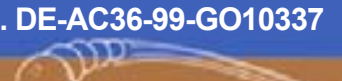




\section{Understanding the Growth of the Cellulosic Ethanol Industry}

D. Sandor and R. Wallace

National Renewable Energy Laboratory

S. Peterson

The Peterson Group

Prepared under Task No. BZ07.1005

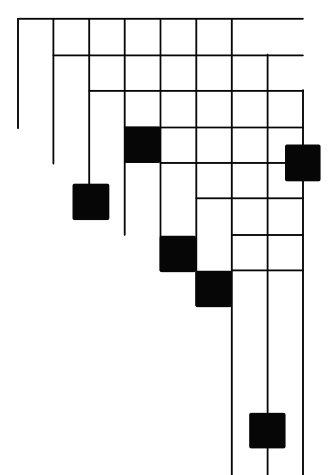




\section{NOTICE}

This report was prepared as an account of work sponsored by an agency of the United States government. Neither the United States government nor any agency thereof, nor any of their employees, makes any warranty, express or implied, or assumes any legal liability or responsibility for the accuracy, completeness, or usefulness of any information, apparatus, product, or process disclosed, or represents that its use would not infringe privately owned rights. Reference herein to any specific commercial product, process, or service by trade name, trademark, manufacturer, or otherwise does not necessarily constitute or imply its endorsement, recommendation, or favoring by the United States government or any agency thereof. The views and opinions of authors expressed herein do not necessarily state or reflect those of the United States government or any agency thereof.

Available electronically at http://www.osti.gov/bridge

Available for a processing fee to U.S. Department of Energy and its contractors, in paper, from:

U.S. Department of Energy

Office of Scientific and Technical Information

P.O. Box 62

Oak Ridge, TN 37831-0062

phone: 865.576 .8401

fax: 865.576 .5728

email: mailto:reports@adonis.osti.gov

Available for sale to the public, in paper, from:

U.S. Department of Commerce

National Technical Information Service

5285 Port Royal Road

Springfield, VA 22161

phone: 800.553.6847

fax: 703.605.6900

email: orders@ntis.fedworld.gov

online ordering: http://www.ntis.gov/ordering.htm 


\section{List of Acronyms}

$\begin{array}{ll}\text { CAFE } & \text { Corporate Average Fuel Economy } \\ \text { OBP } & \text { Office of the Biomass Program } \\ \text { R\&D } & \text { research and development } \\ \text { BSM } & \text { Biomass Scenario Model } \\ \text { CRP } & \text { Conservation Reserve Program } \\ \text { CG } & \text { conventional gasoline } \\ \text { FFV } & \text { flexible fuel vehicle } \\ \text { RFS } & \text { renewable fuel standard } \\ \text { VEETC } & \text { Volumetric Ethanol Excise Tax Credit } \\ \text { ROI } & \text { rate of investment }\end{array}$




\section{Table of Contents}

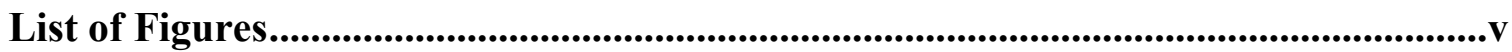

List of Tables .........................................................................................................................

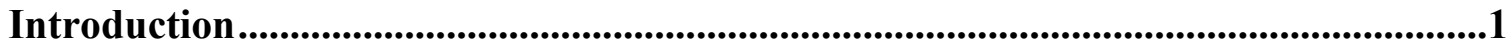

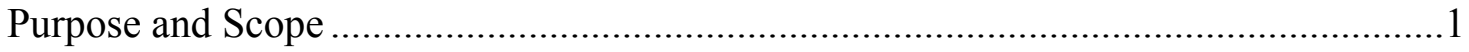

Biomass Scenario Model Description.......................................................................................2

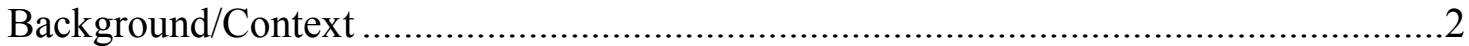

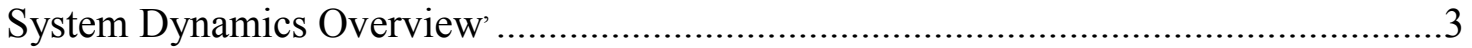

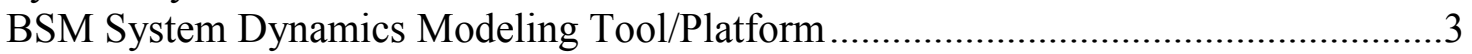

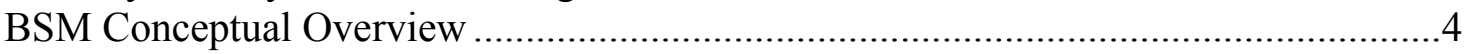

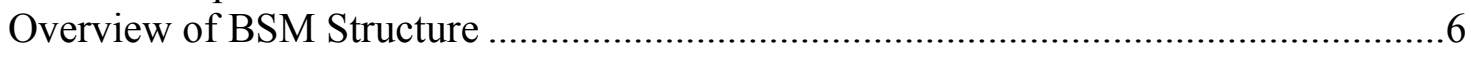

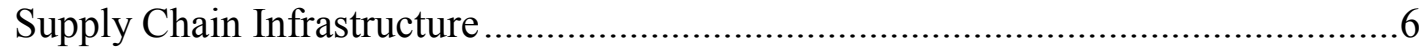

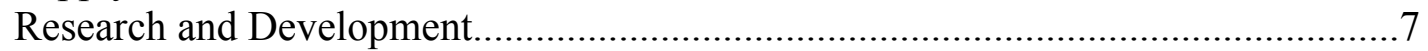

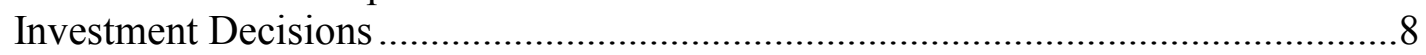

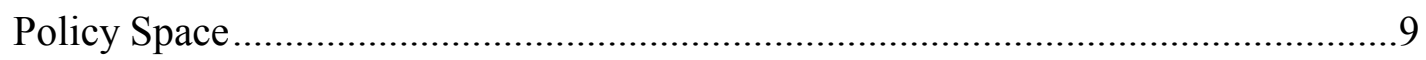

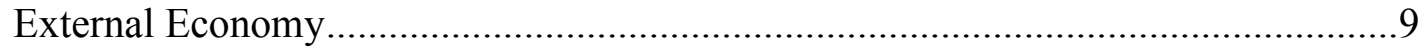

Description of the BSM Base Case and Scenarios Evaluated .........................................9

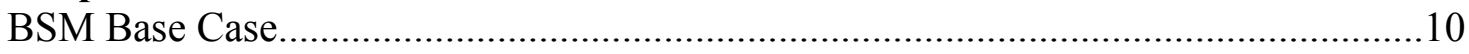

Scenarios for Increasing Cellulosic Ethanol Production...................................................12

Operating Cost Reduction Scenarios .....................................................................13

Capital Cost Reduction Scenario ...................................................................................

Combination Operating and Capital Cost Reduction Scenarios ......................................14

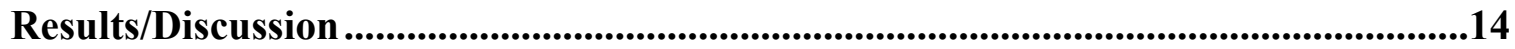

Cellulosic Ethanol Production: Base Case and Five Scenarios ...................................15

Relative Effectiveness of Government Spending in the Scenarios.................................17

Key Performance Parameters Across the Biomass-to-Biofuels Supply Chain...............19

Summary/Conclusions............................................................................................................20

Recommendations/Next Steps.................................................................................................21

Appendix A: An Overview of Symbology Used by the STELLA Modeling Tool......25

Appendix B: Structural Description of the BSM ................................................................27 


\section{List of Figures}

\section{In Text}

Figure 1. Supply Chain Underlying the BSM …………...........................................

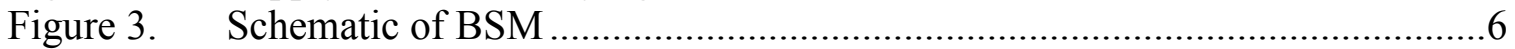

Figure 4. Cellulosic Ethanol Production: Base Case and Five Scenarios …………......15

Figure 5. Impact of Cumulative Government Spending on Cellulosic Ethanol Production Volume in 2017 (excludes VEETC and R\&D Spending)..........18

Figure 6. Government Policy Impact on Industry Capital Investment..........................19

\section{Appendices}

Figure A-1. Simple Structure Accounting for Allocation of Land Between

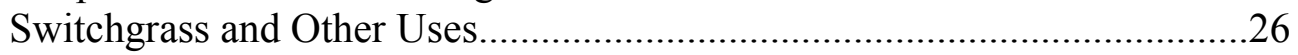

Figure B-1. The Biomass-to-Biofuels Supply Chain ......................................................27

Figure B-2. Simplified View Land Allocation and Feedstock Production ......................29

Figure B-3. Simplified Structure for Tracking Yield Growth in Switchgrass ..................31

Figure B-4. Inputs and Outputs Associated with Feedstock Logistics Module ................33

Figure B-5. Simplified View of Logic Determining Attractiveness of EtOH Plant

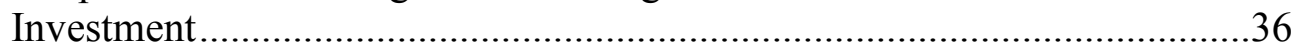

Figure B-6. Accounting Structure Used to Track Plants and Conversion Yields by

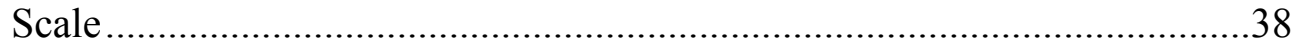

Figure B-7. Representation of Logic Surrounding Pre- and Post-Commercial R\&D......39

Figure B-8. Simplified Representation of Accounting Framework used for BSM Biofuels End Use

\section{List of Tables}

\section{In Text}

Table 1. Biomass Program Goals and BSM Objectives by Supply Chain Element .....4

Table 2. Supply Chain Infrastructures within BSM....................................................

Table 3: $\quad$ Key Base Case Assumptions and Notes ........................................................11

Table 4. Cost of Initiatives - Cumulative Government Spending in 2017 .................17

Table 5. Suggested Impact of Policy on BSM Key Performance Parameters Across Biomass-to-Biofuels Supply Chain in 2017 ..............................................20

\section{Appendices}

Table A-1. Primitives of the system dynamics language as implemented in the

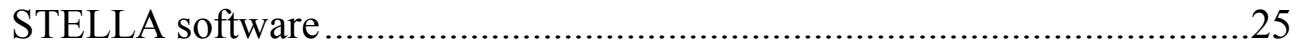

Table B-1. KPIs, Outputs, and Inputs Associated with Feedstock Production Module .28 Table B-2. KPIs, Outputs, and Inputs Associated with Feedstock Logistics Module ....32 Table B-3. KPIs, Outputs, and Inputs Associated with Biofuels Production Module....34

Table B-4. KPIs, Outputs, and Inputs Associated with Biofuels End Use Module.........40 


\section{Introduction}

In the 2007 State of the Union address, the president announced his "Twenty In Ten" goal to cut U.S. gasoline consumption by $20 \%$ over the next 10 years. His proposal focuses on two key elements ${ }^{1}$ :

- An alternative fuels standard that would require the equivalent of 35 billion gallons of renewable and alternative fuels in 2017 (15\% reduction)

- Tighter Corporate Average Fuel Economy (CAFE) standards to reduce projected annual gasoline use by 8.5 billion gallons in 2017 (5\% reduction).

A variety of renewable and alternative fuels - including ethanol, natural gas, propane, and coal-to-liquids - will be required to meet the 35 billion gallon fuel target. The Department of Energy (DOE) Office of the Biomass Program (OBP) has been tasked with estimating the role of ethanol in meeting the goal. The corn ethanol industry, which produced 4.9 billion gallons of ethanol in $2006,{ }^{2}$ is expected to continue to grow rapidly through 2010, contributing an estimated 12 to 20 billion gallons of ethanol by $2016^{3,4}$ OBP is investigating the additional volumes that ethanol from lignocellulosic biomass could contribute to the 2017 goal. Deploying large volumes of cellulosic ethanol in this timeframe will require significant technology advancements in concert with effective government policies to motivate industry transformation across the biomass-to-biofuels supply chain.

OBP is employing a system dynamics approach to understand possible sequences of events behind the deployment of biofuels technology. A prototype dynamic system model, the Biomass Scenario Model (BSM), has been developed to investigate potential market penetration scenarios for cellulosic ethanol and to strategically assess OBP's research and development (R\&D) and deployment strategies.

\section{Purpose and Scope}

This report identifies, outlines, and documents a set of plausible scenarios for producing significant quantities of lignocellulosic ethanol in 2017. These scenarios can provide guidance for setting government policy and targeting government investment to the areas with greatest potential impact. A prototype version of the BSM was used to develop the scenarios. The analysis underlying the scenario-generation exercise focuses on understanding the impact of two types of proposed government policies on the deployment of cellulosic biofuels technologies:

\footnotetext{
${ }^{1}$ Twenty in Ten: Strengthening America's Energy Security. http://www.whitehouse.gov/infocus/energy

${ }^{2}$ Ethanol Industry Outlook 2007: Building New Horizons. (February 2007). Renewable Fuels Association. http://www.ethanolrfa.org/objects/pdf/outlook/RFA_Outlook_2007.pdf

${ }^{3}$ Agricultural Baseline Projections. (February 2007). Economic Research Service, U.S. Department of Agriculture. http://www.ers.usda.gov/Briefing/Baseline/

${ }^{4}$ Ethanol Transportation Backgrounder: Expansion of U.S. Corn-based Ethanol from the Agricultural Transportation Perspective. (September 2007). Agricultural Marketing Sector. U.S. Department of Agriculture. http://www.ams.usda.gov/tmd/TSB/EthanolTransportationBackgrounder09-17-07.pdf
} 
- Policies focused on reducing operating costs associated with cellulosic ethanol production. These policies include payments to feedstock producers and subsidies associated with production of cellulosic ethanol.

- Policies focused on reducing capital costs associated with cellulosic ethanol production. These policies include capital subsidies for construction of full-scale cellulosic ethanol production plants.

Consistent with the goal of generating a plausible set of scenarios around production of lignocellulosic ethanol in 2017, this report is not intended to provide a comprehensive analysis of all policy options. To support future, more comprehensive analyses, BSM is currently in process of significant modification and revision.

This report begins with a high-level description of BSM. Then, it discusses the scenarios generated and evaluated. Finally, the report summarizes key results and offers recommendations for future work. The appendices provide more detailed views into the:

- System dynamics language elements (Appendix A)

- Internal logic of BSM (Appendix B).

\section{Biomass Scenario Model Description}

\section{Background/Context}

The BSM was developed as a prototype tool for investigating the dynamics associated with the potential evolutionary trajectories of a biofuels industry in the United States. The BSM describes the deployment of biofuels technology in the marketplace across the biomass-to-biofuels supply chain. This model tracks the deployment of ethanol given development of new technologies (in feedstock collection, conversion, and vehicles) and the reaction of the investment community to those technologies in light of the competing oil market, vehicle demand for biofuels and various government policies over time. This prototype was originally developed for the Role of Biomass in America's Energy Future $(\mathrm{RBAEF})^{5}$ project. It is currently undergoing significant revision in order to provide a richer view into feedstock production and logistics, conversion technology, fuel infrastructure, and markets.

The BSM uses the system dynamics framework for its conceptual underpinnings to understand the dynamic interactions across the entire biomass-to-biofuels system, or supply chain. This supply chain, in turn, provides a broad landscape for considering the emergence of a sustainable industry. Additionally, it serves as a focal point for the integration of other, more detailed and narrowly-focused studies of various components of the supply chain. These other analyses can include, for example:

5 "The Role of Biomass in America's Energy Future" a joint project initiated in 2003 of Dartmouth College, Princeton University, University of Tennessee, Michigan State University, Argonne National

Laboratory, National Renewable Energy Laboratory, Natural Resources Defense Council and sponsored by US DOE and the National Commission on Energy Policy. http://engineering.dartmouth.edu/rbaef/index.shtml 
- Feedstock logistics analyses

- Agricultural economics analyses

- Process models

- Integrated biorefinery models

- Life cycle models

- Economic models

- Market analyses.

\section{System Dynamics Overview ${ }^{6,7}$}

System dynamics is a methodology for analyzing the behavior of complex feedback systems over time. The methodology and computer simulation modeling techniques originated at the Massachusetts Institute of Technology in the 1950s as tools to improve understanding of industrial processes. System dynamics has been productively applied to a wide range of industrial and organizational, and policy-oriented systems problems over the past 40 years. $^{8}$

Systems problems tend to share four important characteristics:

- They involve dynamics - change over time is a defining characteristic of the issue-space

- Multiple players and diverse interests interact to impact system performance

- Interdependencies among different sub-systems and processes are critical to system performance

- Communication of issues, structure, and leverage points can be very difficult.

Using these criteria as a filter, the potential evolutionary trajectories of a biofuels industry in the United States can be seen as a classic systems problem. The issues involve dynamics around developing and sustaining an entire industry. Multiple players are involved - ranging from farmers to venture capitalists to automobile manufacturers to congressional policy makers. Failure to develop any link within the supply chain can thwart development of the industry. And finally, because both detail and dynamic complexity is so rich, it can be very difficult to understand and communicate the system of interactions from the perspective of a single disciplinary framework.

\section{BSM System Dynamics Modeling Tool/Platform}

The STELLA ${ }^{\mathrm{TM}}$ software tool is the platform for the BSM development effort. STELLA is a "systems thinking" software package developed specifically for dynamic systems modeling by ISEE Systems. The software provides a simple, yet powerful visual language for representing dynamic systems and processes, thus making the system

6 "US DOE Introduction to System Dynamics: A Systems Approach to Understanding Complex Policy Issues, Version 1" (1997) US Department of Energy http://www.systemdynamics.org/DL-IntroSysDyn/ 7 System Dynamics Society Website (visited 8-11-07) http://www.systemdynamics.org/ (Updated 4/25/07)

${ }^{8}$ See, for example, Sterman, John. Business Dynamics: Systems Thinking and Modeling for a Complex World. Homewood, IL: Irwin/McGraw-Hill, 2000, which provides a thorough treatment of the framework and its application areas. 
dynamics framework accessible as a desktop tool for analysts and policy makers. Its relatively intuitive nature is well suited to the "what if" scenario building needed to understand the possible paths for a new bioindustry. For more information on STELLA, see Appendix A.

\section{BSM Conceptual Overview}

The initial development of the BSM was motivated by a desire to understand "transition dynamics" associated with the development of a lignocellulosic ethanol industry. Early in the effort, it was recognized that an integrative systems view into the industry supply chain was required. Figure 1 provides a conceptual overview of the supply chain for lignocellulosic ethanol.

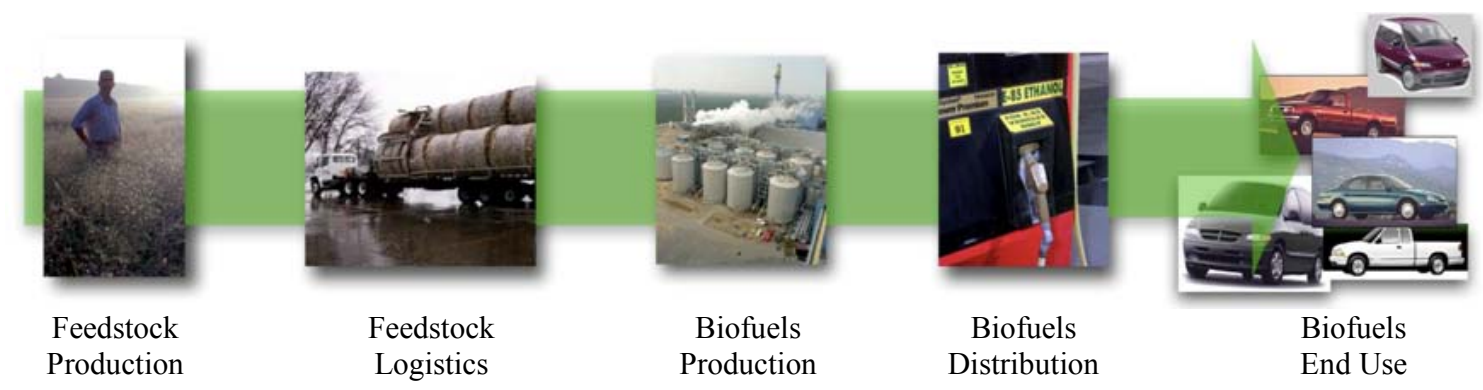

Figure 1. Supply Chain Underlying the BSM

The BSM is organized around the five major elements of the biomass-to-biofuels supply chain for the future biofuels industry. The OBP's overarching goal for each element of the supply chain (as described in the OBP FY07 Multi-Year Program Plan ${ }^{9}$ ) and the objective of the analogous BSM module are summarized in Table 1.

Table 1. Biomass Program Goals and BSM Objectives by Supply Chain Element

\begin{tabular}{|l|l|l|}
\hline $\begin{array}{l}\text { Supply Chain } \\
\text { Element }\end{array}$ & \multicolumn{1}{|c|}{ Biomass Program Goal } & \multicolumn{1}{c|}{ Current BSM Module Objective } \\
\hline $\begin{array}{l}\text { Feedstock } \\
\text { Production }\end{array}$ & $\begin{array}{l}\text { Produce large, sustainable } \\
\text { supplies of regionally available } \\
\text { biomass }\end{array}$ & $\begin{array}{l}\text { Provide a basis for the production of cellulosic } \\
\text { feedstocks, respecting the constraints imposed by } \\
\text { the agricultural land base in a manner consistent } \\
\text { with economics. }\end{array}$ \\
\hline $\begin{array}{l}\text { Feedstock } \\
\text { Logistics }\end{array}$ & $\begin{array}{l}\text { Implement biomass feedstock } \\
\text { infrastructure, equipment and } \\
\text { systems (biomass harvesting, } \\
\text { collection, storage, } \\
\text { preprocessing and } \\
\text { transportation) }\end{array}$ & $\begin{array}{l}\text { Account for the cost associated with moving } \\
\text { biomass feedstock from the point of production } \\
\text { (i.e., farm gate) to the point of conversion (i.e., } \\
\text { plant gate). (Note: The current BSM focuses on } \\
\text { feedstock transportation only -it does not } \\
\text { account for the other logistics areas.) }\end{array}$ \\
\hline $\begin{array}{l}\text { Biofuels } \\
\text { Production }\end{array}$ & $\begin{array}{l}\text { Deploy cost-effective, integrated } \\
\text { biomass-to-biofuels conversion } \\
\text { facilities }\end{array}$ & $\begin{array}{l}\text { Represent biomass-to-ethanol conversion process } \\
\text { and the logic associated with the decision to add } \\
\text { new plant to the system. }\end{array}$ \\
\hline
\end{tabular}

\footnotetext{
${ }^{9}$ Biomass Multi-Year Program Plan. (November 2007). Office of the Biomass Program, Office of Energy Efficiency and Renewable Energy, U.S. Department of Energy. http://www1.eere.energy.gov/biomass/pdfs/biomass_program_mypp.pdf
} 


\begin{tabular}{|l|l|l|}
\hline $\begin{array}{l}\text { Biofuels } \\
\text { Distribution }\end{array}$ & $\begin{array}{l}\text { Implement biofuels distribution } \\
\text { infrastructure (storage, blending, } \\
\text { transportation, and dispensing) }\end{array}$ & $\begin{array}{l}\text { No model structure currently exists around fuel } \\
\text { transport from point to production to point of use. } \\
\text { (During development of the BSM, a simplifying } \\
\text { assumption was made that fuel transportation } \\
\text { would not limit the development of the biofuels } \\
\text { industry.) }\end{array}$ \\
\hline Biofuels End Use & $\begin{array}{l}\text { Expand public availability of } \\
\text { biofuels-compatible vehicles } \\
\text { with same performance as } \\
\text { petroleum fuels }\end{array}$ & $\begin{array}{l}\text { Represent the consumption of fuel ethanol based } \\
\text { on the potential demand for ethanol as E10 and } \\
\text { E85 and the impacts of vehicle mix and } \\
\text { efficiency. }\end{array}$ \\
\hline
\end{tabular}

From the OBP perspective, this supply chain provides the basic framework to align and coordinate the efforts of the large and diverse group of stakeholders that will play a critical role in realizing the president's challenging biofuels goals. In the context of systems dynamics, the BSM supply chain framework creates the potential to analyze and understand feedback effects between disparate processes as the industry evolves over time. A highly simplified representation of key feedbacks captured within the supply chain framework is shown in Figure 2.

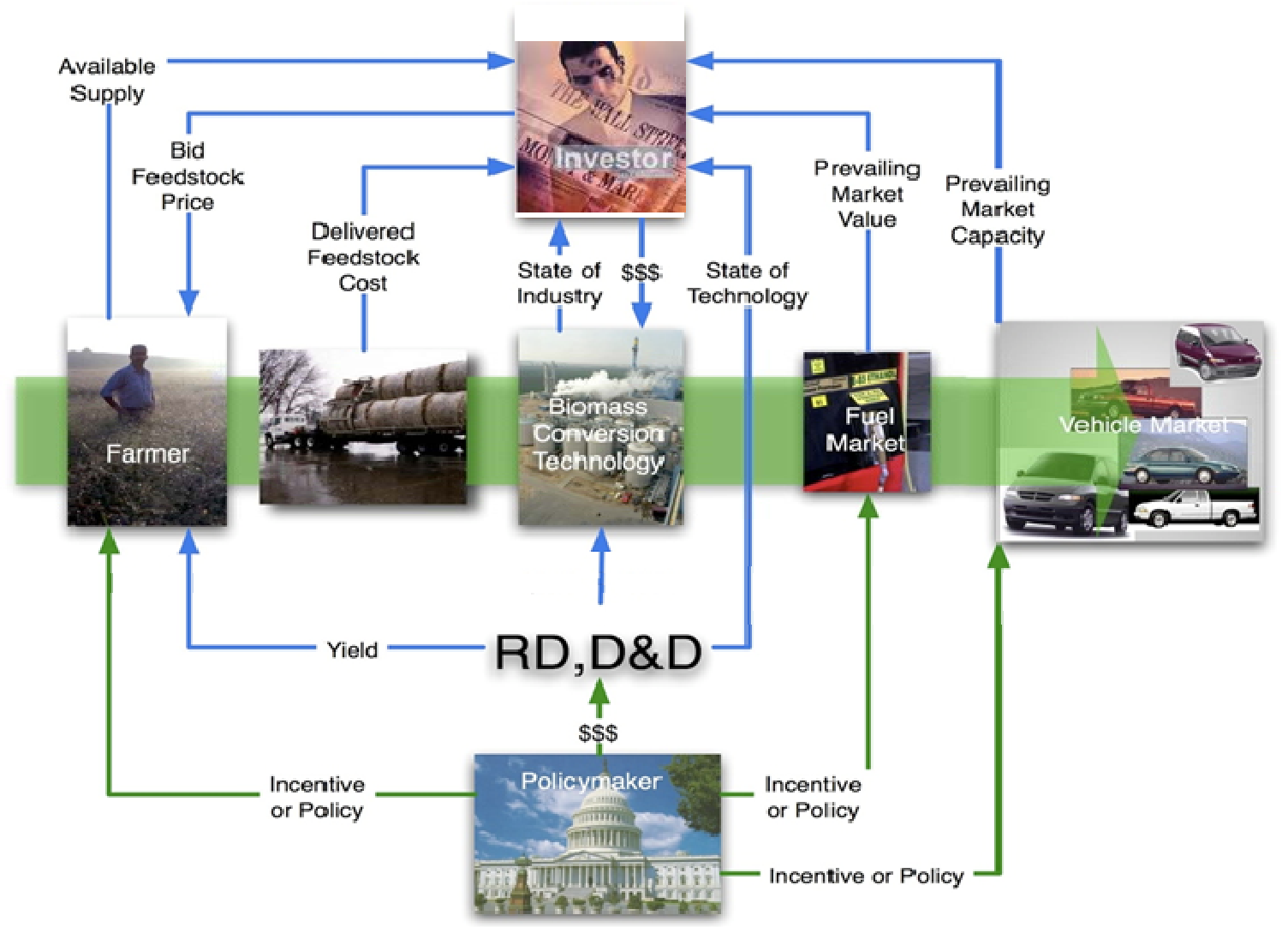

Figure 2. Key Feedbacks Captured in the BSM

As suggested in Figure 2, for example, limited availability of feedstock can constrain the rate of growth in cellulosic ethanol production capacity. Meanwhile, mismatches between available supply and quantity demanded at a given price will tend to drive changes in price. 


\section{Overview of BSM Structure}

Figure 3 provides a high-level view of the BSM and points to the key features and components of the dynamic framework - supply chain, supply infrastructure, R\&D, investment decision, policy space, and external economy — which are described here.

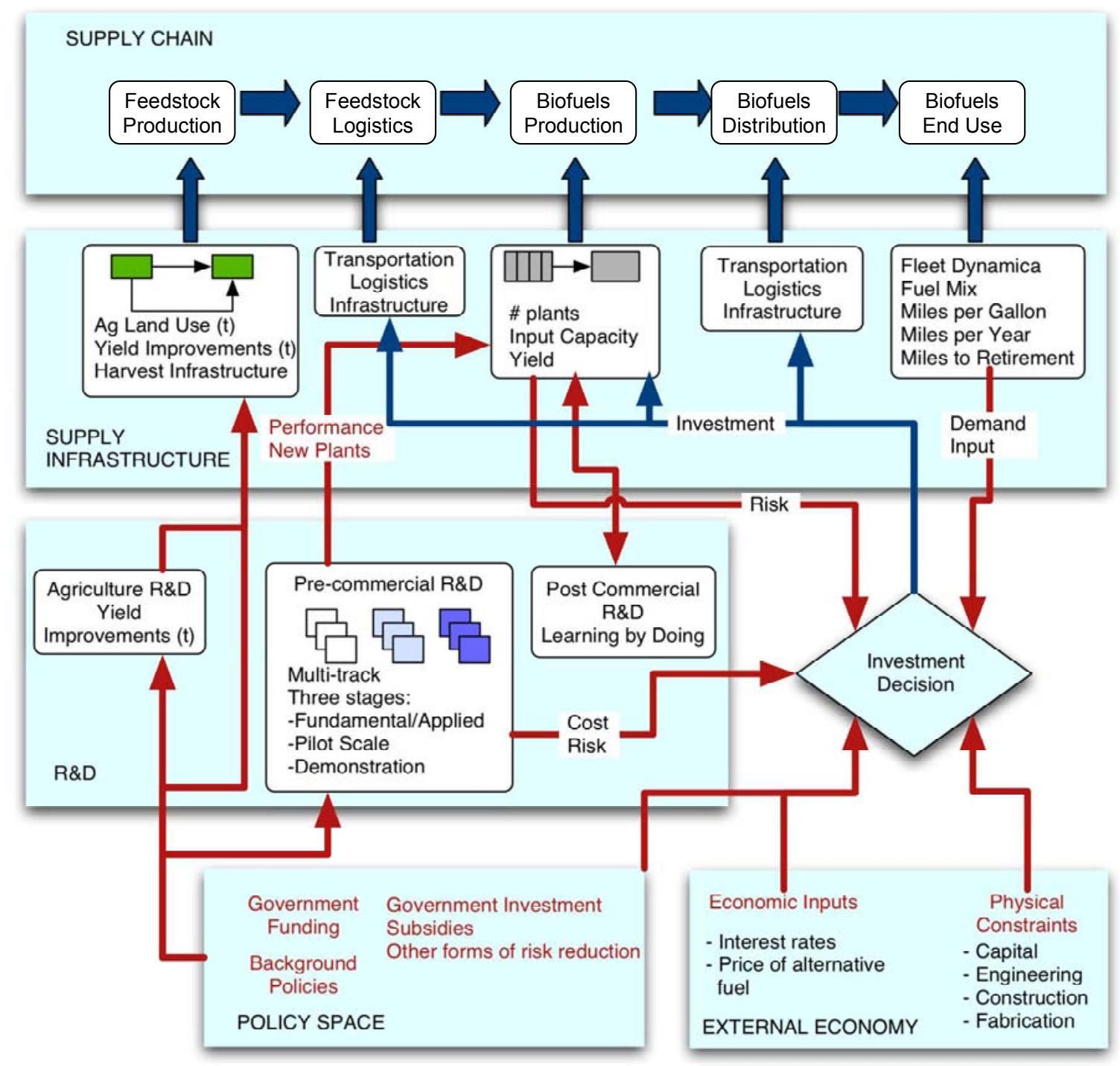

Figure 3. Schematic of BSM

\section{Supply Chain Infrastructure}

At each stage in the supply chain, the BSM seeks to represent the physical infrastructure required to capture the dynamics of the emerging industry. Table 2 identifies key supply chain infrastructures and describes how they are handled within BSM. 
Table 2. Supply Chain Infrastructures within BSM

\begin{tabular}{|c|c|c|}
\hline $\begin{array}{l}\text { Stage in } \\
\text { Supply Chain }\end{array}$ & Infrastructure & Notes \\
\hline \multirow[t]{4}{*}{$\begin{array}{l}\text { Feedstock } \\
\text { Production }\end{array}$} & $\begin{array}{l}\text { Agricultural Land } \\
\text { Use }\end{array}$ & $\begin{array}{l}\text { - Two land bases: Prime and Conservation Reserve Program } \\
\text { (CRP) land } \\
\text { - Allocation between dedicated cellulosic crop (switchgrass) and } \\
\text { other crops }\end{array}$ \\
\hline & Residues & - Simple price/supply curves for agricultural, forest residues \\
\hline & Yield Dynamics & $\begin{array}{l}\text { - Capture yield changes for herbaceous energy crops } \\
\text { - Distinguish between yield growth at lab/research station and } \\
\text { yield growth on the farm } \\
\text { - Yield growth driven by R\&D efforts }\end{array}$ \\
\hline & $\begin{array}{l}\text { Supply/Demand } \\
\text { Dynamics }\end{array}$ & $\begin{array}{l}\text { Endogenous pricing structure resolves supply/demand } \\
\text { discrepancies (demand driven by cellulose-to-ethanol } \\
\text { conversion capacity) } \\
\text { - Cellulosic residues respond to price changes through simple } \\
\text { supply curve }\end{array}$ \\
\hline $\begin{array}{l}\text { Feedstock } \\
\text { Logistics }\end{array}$ & - & $\begin{array}{l}\text { - Build up of infrastructure not explicitly represented } \\
\text { - Farm-gate to plant-gate costs driven by distance to plant }\end{array}$ \\
\hline $\begin{array}{l}\text { Biofuels } \\
\text { Production }\end{array}$ & $\begin{array}{l}\text { Conversion } \\
\text { Facilities }\end{array}$ & $\begin{array}{l}\text { - Track design, construction, and on-line facilities (at three scales) } \\
\circ \text { Demonstration scale } \\
\circ \text { Pioneer scale } \\
\circ \quad \text { Full scale } \\
\end{array}$ \\
\hline $\begin{array}{l}\text { Biofuels } \\
\text { Distribution }\end{array}$ & - & $\begin{array}{l}\text { - Infrastructure not currently represented-assumed not to be } \\
\text { rate-limiting }\end{array}$ \\
\hline \multirow[t]{3}{*}{ Biofuels End Use } & Vehicle Mix & $\begin{array}{l}\text { - Accounting Structure for Multiple Vehicle Types } \\
\circ \quad \text { Conventional gasoline (CG) cars } \\
\circ \quad \text { CG light trucks } \\
\circ \text { Flexible fuel vehicle (FFV) cars } \\
\circ \quad \text { FFV light trucks } \\
\text { "Other" cars (catch-all category including diesel, off-road } \\
\text { diesel, plug in hybrids, hydrogen vehicles) } \\
\text { - "Other" trucks } \\
\text { - Three age classes for vehicles to capture vehicle vintaging } \\
\text { - Mix of new vehicles entering system over time captured as user- } \\
\text { defined scenario }\end{array}$ \\
\hline & Vehicle Efficiency & $\begin{array}{l}\text { - Tracked by vehicle age and type } \\
\text { - Efficiency of new vehicles entering system over time captured } \\
\text { as user-defined scenario }\end{array}$ \\
\hline & $\begin{array}{l}\text { Other Vehicle } \\
\text { Attributes }\end{array}$ & $\begin{array}{l}\text { - Miles driven per year captured as user-defined scenario } \\
\text { - Vehicle projected lifetime captured as user-defined scenario }\end{array}$ \\
\hline
\end{tabular}

\section{Research and Development}

As suggested in Figure 3, R\&D activities impact both the feedstock production and biofuels production stages of the supply chain. BSM explicitly represents R\&D efforts associated with yield growth in herbaceous perennial cellulosic crops, pre-commercial conversion technology, and post-commercial "learning by doing" activities. 
- Agricultural $R \& D$ is represented simply. Cumulative investment in R\&D is assumed to drive yields for herbaceous perennial cellulosic feedstocks. The specific investment pattern can be defined by the user as a scenario. In the base run, herbaceous perennial cellulosic feedstock yield as the research level grows from five tons per acre per year to slightly over seven tons per acre per year. A one-year dwell time is assumed for translating yield growth at the research level into yield growth on the farm.

\section{- Conversion $R \& D$}

o Pre-commercial $R \& D$ is represented in some detail. Two technology tracks are represented within the model. Each technology track exhibits a unique assumed curve relating cumulative R\&D investment against yield. This in turn is used to as an input to the model logic around plant capital and operating cost metrics. For each track, R\&D is represented at fundamental and applied R\&D and pilot scale operations. Higher levels of cumulative investment lead to increased yields, with resultant lowered costs.

o Post-commercial $R \& D$ is captured through learning curve dynamics. As cumulative industry output doubles, conversion yields seek an asymptote given by an assumed maximum mature technology yield. In the base run, the progress ratio for learning curve dynamics is set to an assumed value of 0.8 . Each doubling in cumulative industry output is associated with conversion yield increases of $80 \%$ of the gap between prior yield and mature technology yield.

R\&D and associated yield improvements for residues are handled as a scenario. The initial agricultural residue supply curve taken from POLYSYS, is assumed to shift linearly at a rate of $1 \%$ per year.

\section{Investment Decisions}

Investors process multiple cost, risk, and external inputs to determine when and how much to invest. The investment decision is central to the operation of the model. Investor decision-making is driven by multiple inputs, including:

- Potential demand for ethanol (as oxygenate in E10, and as E85)

- Level of capital subsidy

- Level of fuel subsidy (e.g., VEETC)

- Level of feedstock subsidy (i.e., grower payment)

- Relative price of gasoline

- Plant capital cost (dependent on scale of plant and experience at previous scales)

- Perceived risk (dependent on industry maturity)

- Interest rates

- Investor type (possible to select aggressive, moderate, or risk-averse investor). 


\section{Policy Space}

The BSM provides a framework for exploring the impact of government policies on industry development. Government policy intervention points can occur along the supply chain and within the R\&D community. Several policy options are currently being considered, including:

- Feedstock subsidies. These subsidies are aimed at reducing the delivered cost of cellulosic feedstock material to the plant gate. Magnitude, timing, and duration of subsidies can be varied for particular simulation experiments.

- Renewable fuel standard (RFS). A RFS can be switched on or off. The specific magnitude and timing reflects current legislation, but may be modified to reflect different scenarios.

- Ethanol fuel subsidies. Specific magnitude and timing can be modified to explore different policies. Subsidies can be applied to all ethanol fuels, or specifically to cellulosic ethanol fuel.

- Conversion plant capital subsidies. Subsidies can be configured on a scalespecific (i.e., demonstration, pioneer, full scale) basis. Policy levers include the total (cumulative) dollar amount available for subsidies, the maximum percent of per-project cost to be subsidized, and the maximum dollar amount to subsidize per project.

\section{External Economy}

Inputs associated with the external economy are used to drive different background scenarios for model analysis. These inputs include economic factors, such as interest rates and scenarios around the price of gasoline. They also include physical limits (such as the availability of construction capacity) which may constrain the rate of development of the industry.

For additional information on the BSM, see Appendix B, which describes the BSM in some detail from the perspective of:

- Supply chain module purpose and approach

- Key module outputs and inputs

- Structure, logic, and decision rules embedded into the module

- Policy levers and scenario variables that impact the module.

\section{Description of the BSM Base Case and Scenarios Evaluated}

This section provides a description of baseline output along with a set of scenarios generated with the BSM. In considering the model results described in this report, it is important to keep in mind the prototype, provisional nature of the model, which is used to generate the output. In particular: 
- Because the model is a prototype, the scenarios generated by the model can in no way be considered to be definitive. While BSM developers consider the scenarios to be plausible, they also consider the model to be very much a work in process. Current development efforts are focused on strengthening the structure, assumptions, and data used to generate BSM output. It is appropriate to view model scenarios here with an attitude of healthy skepticism around assumptions, relationships, and data.

- The model results are scenarios not predictions. A good use of the scenarios presented here is to envision, in broad terms, plausible future conditions. It would be improper to use the scenarios described here to make point-in-time predictions that never come to pass.

- The feedback loop structure within BSM is rich. In the conversion model in particular, multiple positive feedbacks are latent within the model's structure. Under some sets of policy scenarios, positive feedbacks can become activated, driving the industry toward self-sustaining growth. It can be useful to assess the scenarios by considering the degree to which an initiative moves the industry toward self-sustaining growth over time. This is different than viewing output at a single point in time.

\section{BSM Base Case}

The Base Case model used in this analysis is a modified version of the original RBAEF prototype model. This Base Case (model bw070829-base-sp.STM) reflects the current state of the industry and policy incentives now in place. The key Base Case assumptions are summarized in Table 3. Policy incentives represented in the Base Case include:

- Volumetric Ethanol Excise Tax Credit (VEETC)

$\circ \$ 0.51$ per gallon of ethanol blended through $2010^{10}$

- Integrated biorefinery capital subsidies

○ \$385 million for demonstration plants (50 dry tons per day) awarded in 2005 (DOE:industry cost share ratio of $40: 60)^{11}$

○ \$385 million for pioneer plants (500 dry tons per day) awarded in 2007

(DOE:industry cost share ratio of 40:60 ${ }^{12}$

The Base Case scenario results in the production of 500 million gallons of cellulosic ethanol in 2017.

\footnotetext{
${ }^{10}$ Volumetric Ethanol Excise Tax Credit as per EPAct; http://thomas.loc.gov/cgibin/query/D?c110:1:./temp/ c110GQLElc::

${ }^{11}$ April 2002 solicitation for "Biomass Research and Development for the Production of Fuels, Power, Chemicals and other Economical and Sustainable Products" projects. Note that these projects were actually smaller scale pilot, rather than demonstration scale, efforts.

${ }^{12}$ EPAct 2005 Section 932 Solicitation for 700 tons/day cellulosic ethanol production plants
} 
Table 3: Key Base Case Assumptions and Notes

\begin{tabular}{|c|c|c|}
\hline $\begin{array}{l}\text { Stage in } \\
\text { Supply } \\
\text { Chain }\end{array}$ & Topic & Assumption/note \\
\hline \multirow[t]{7}{*}{$\begin{array}{l}\text { Feedstock } \\
\text { Production }\end{array}$} & Agricultural residues & $\begin{array}{l}\text { - Supply curve taken from ORNL Analysis } \$ 50 / \text { ton } \\
\text { price } \rightarrow 110 \mathrm{M} \text { tons per year }\end{array}$ \\
\hline & Forest residues & $\begin{array}{l}\text { - Supply curve taken from ORNL Analysis } \$ 50 / \text { ton price } \rightarrow \\
57 \mathrm{M} \text { tons per year }\end{array}$ \\
\hline & $\begin{array}{l}\text { Herbaceous cellulosic } \\
\text { energy crop supply }\end{array}$ & $\begin{array}{l}\text { - Consistent with University of Tennessee POLYSYS land } \\
\text { competition analysis for switchgrass on prime cropland }\end{array}$ \\
\hline & $\begin{array}{l}\text { Herbaceous cellulosic } \\
\text { energy crop yield } \\
\text { (research setting) }\end{array}$ & $\begin{array}{l}\text { - Initially } 5 \text { tons/acre per year, rising } 1.5 \% \text { per year to } 13 \\
\text { tons/acre per year in } 2050\end{array}$ \\
\hline & $\begin{array}{l}\text { Herbaceous cellulosic } \\
\text { energy crop yield } \\
\text { (farm/commercial } \\
\text { setting) }\end{array}$ & $\begin{array}{l}\text { One year dwell time between yield increases in research } \\
\text { setting and yield increases in farm/commercial settings. } \\
\text { NOTE: In the Base Case, less than } 10 \% \text { of } 2017 \text { total } \\
\text { cellulosic biomass comes from herbaceous cellulosic energy } \\
\text { crop }\end{array}$ \\
\hline & CRP land & $\begin{array}{l}\text { - Base run allows CRP land to be converted to herbaceous } \\
\text { cellulosic energy crop production. In base run, majority of } \\
2017 \text { cellulosic energy crop production comes from CRP } \\
\text { land. }\end{array}$ \\
\hline & Corn market & $\begin{array}{l}\text { - Initial corn price set at } \$ 1.90 / \mathrm{bu} \\
\text { - Non-EtOH demand for corn assumed to increase linearly at } \\
0.8 \% \text { of initial value each year } \\
\text { - EtOH production from corn grows to max value of } 10 \\
\text { billion gal/yr in } 2010 \\
\text { - Corn yield assumed to grow linearly from } 160 \text { to } 180 \mathrm{bu} / \mathrm{A} \\
\text { over the period of } 2005 \text { to } 2017 \\
\text { - Corn price adjusts to resolve supply/demand imbalances }\end{array}$ \\
\hline $\begin{array}{l}\text { Feedstock } \\
\text { Logistics }\end{array}$ & Delivery mechanism & $\begin{array}{l}\text { - Truck delivery up to } 50 \text { miles to plant } \\
\text { - No assumed constraints (e.g., highway capacity) to delivery } \\
\text { of feedstocks from point of production to plant gate }\end{array}$ \\
\hline \multirow[t]{4}{*}{$\begin{array}{l}\text { Biofuels } \\
\text { Production }\end{array}$} & Conversion yields & $\begin{array}{l}\text { - Maximum potential conversion yield conversion yield : } 105 \\
\text { gal/dry ton biomass }\end{array}$ \\
\hline & Plants & $\begin{array}{l}\text { - All plants constructed successfully come on line } \\
\text { - Three year plant planning, permitting, construction time } \\
\text { - Commercial-scale plant: } 5000 \text { TPD }\end{array}$ \\
\hline & Target price & $\begin{array}{l}\text { - } \$ 1.07 \text { per gallon ethanol nominal price target in } 2012^{13} \text { at } \\
\text { pilot scale }\end{array}$ \\
\hline & $\begin{array}{l}\text { Investor financing } \\
\text { detail }\end{array}$ & $\begin{array}{l}\text { - Required ROI for equity investor for "new" industry }=30 \% \\
\text { - Required ROI for equity investor for "mature" industry = } \\
10 \% \\
\text { - Aggressive equity investor assumed: Industry moves from } \\
\text { "new" to "mature" as annual production capacity moves } \\
\text { from } 0 \text { to } 100 \mathrm{M} \text { gal/year } \\
\text { - Capital cost growth factor of } 2.22 \mathrm{x} \text { for "new" industry; } \\
\text { declines to } 1.0 \mathrm{x} \text { as annual production capacity moves from } 0 \\
\text { to } 500 \mathrm{M} \text { gal/yr } \\
\text { - Debt:Equity Mix = 40:60 }\end{array}$ \\
\hline
\end{tabular}

\footnotetext{
${ }^{13}$ Note: Ethanol price target in $2002 \$$ (Upcoming BSM revision will update ethanol price target to $2007 \$$ to match target in FY07 MYPP).
} 


\begin{tabular}{|c|c|c|}
\hline & $\begin{array}{l}\text { Venture Capital } \\
\text { Detail }\end{array}$ & $\begin{array}{l}\text { - VC investment enabled } \\
\text { - VC Investment in Demonstration-scale plants triggered } \\
\text { when: } \\
\circ \quad \text { Sufficient pilot scale effort has been logged } \\
\circ \quad \text { Expected EtOH price from full scale facilities }< \\
\text { expected gasoline wholesale price at wholesale on BTU } \\
\text { equivalency basis } \\
\circ \quad \text { Industry capacity }<20 \mathrm{M} \mathrm{gal} / \mathrm{yr} \\
\end{array}$ \\
\hline $\begin{array}{l}\text { Biofuels } \\
\text { Distribution }\end{array}$ & & $\begin{array}{l}\text { - No modeling done. Assumes no barriers to distribution and } \\
\text { refueling stations (i.e., assumes infrastructure development } \\
\text { not rate-limiting) }\end{array}$ \\
\hline \multirow[t]{2}{*}{$\begin{array}{l}\text { Biofuels End } \\
\text { Use }\end{array}$} & $\begin{array}{l}\text { Flexible-Fuel } \\
\text { Vehicles (FFV) }\end{array}$ & $\begin{array}{l}\text { - Influx of new FFV vehicles ramps to } 25 \% \text { of total new } \\
\text { vehicle production by } 2012 \\
\text { - Total FFV vehicles in use grow from } \sim 1.5 \mathrm{M} \text { in } 2006 \text { to } \\
\sim 30 \mathrm{M} \text { in } 2017\end{array}$ \\
\hline & Fuel Market & $\begin{array}{l}\text { - Oil price based on "AEO } 2006 \text { High Oil Price Projection" } \\
\text { - ORNL refinery model analysis used to predict ethanol } \\
\text { blending value as function of demand }\end{array}$ \\
\hline
\end{tabular}

\section{Scenarios for Increasing Cellulosic Ethanol Production}

Technical and financial risk are significant barriers to the development of a commercial cellulosic ethanol industry. To reduce this risk and facilitate initial investments while the industry is in its infancy, significant federal funding will be required. The scenarios developed for this analysis take a "conversion facility-centric" approach to motivating cellulosic ethanol production, recognizing that to enable greatly increased production in 2017 and beyond, it is necessary to improve substantially the economic proposition associated with building new or first-of-a-kind facilities. Government can improve the economic proposition in two ways: (1) by lowering operating costs and (2) by reducing the capital cost of these first facilities. As the first facilities are built and come on-line (the model assumes successful investments), risk can be reduced sufficiently to enable the industry to grow of its own accord. The ultimate goal of government policies, then, is to make this transition or tipping point occur as quickly as possible.

In its current prototype state, BSM can be used to explore potential impacts of policy incentives on cellulosic ethanol production, including those that focus on influencing the biomass production, biomass transport and biofuels production elements of the biomassto-biofuels supply chain. Currently, however, BSM is not set up to address policies aimed at influencing the biofuels distribution and biofuels use stages in the supply chain. BSM is currently undergoing significant revision. As a more robust version of the model is developed, initiatives along the entire supply chain will be explored.

The BSM assesses the impact of a variety of factors on the attractiveness of building cellulosic ethanol production facilities. Factors such as cost, risk, feedstock availability, and demand for ethanol are considered in the calculations to determine when and how much to invest in these facilities (as summarized in the previous Investment Decisions discussion and detailed in Appendix B). Essentially, the "attractiveness to build" is a reflection of the minimum selling price of ethanol necessary to satisfy the required return 
on investment. The attractiveness of investing in new cellulosic ethanol is calculated by comparing the minimum ethanol selling price with an appropriate market price of the competing product. Initially, ethanol (both corn ethanol and cellulosic ethanol) is assumed to fill the oxygenate market, and then the competing product is considered to be motor gasoline.

To generate scenarios, we explored three federal policy options that have the potential to increase the production of cellulosic ethanol. As indicated, these policy options either reduce operating costs or reduce required capital investment:

- Lowering the operating cost

○ Feedstock grower payment

○ (\$20/ton; 2007-2017)

o Cellulosic ethanol production subsidy

○ (\$2/gallon up to 500M gallon cellulosic ethanol produced; 2009-until production volume met)

- Lowering the capital investment

○ Capital subsidy for commercial-scale (5000 tpd) cellulosic ethanol production plants

- $\quad(40 \%$ per project up to a total government expenditure of $\$ 1.5$ billion; 2009-until funds depleted)

These policy options were used individually and in combination, by enabling specific policy levers in the BSM, to generate five distinct scenarios. The scenarios were then evaluated and compared with the Base Case model. In all five scenarios, the current policy incentives are maintained and all assumptions match the Base Case except as described below.

\section{Operating Cost Reduction Scenarios}

Grower Payment (model bw070829-Feedstock.STM). Targeted at the initial stage in the supply chain, a grower payment subsidy aims to reduce the cost of feedstocks for producers at the plant gate while providing an incentive for producers to provide feedstock. By providing a subsidy to growers in the form of a grower payment, this lever reduces the amount that conversion facilities will need to pay to acquire feedstock for their operations. The grower payment scenario examines the impact of feedstock subsidies in the form of a $\$ 20 /$ dry ton (unadjusted for inflation) grower payment through 2017. In the BSM, this is controlled via the Government Policy Input page; the feedstock subsidy per ton variable is set at \$20/ton through 2017. This variable is used to calculate the subsidized feedstock cost per ton variable, which feeds into the attractiveness to build calculations.

Production Subsidy (model bw070829-EtOH Subsidy.STM). Production subsidies directly target the conversion processes by providing a payment for the output of facilities. The production subsidy scenario looks at the impact of cellulosic ethanol 
production subsidies in the form of a $\$ 2 /$ gallon payment (unadjusted for inflation) for the first 500M gallons of cellulosic ethanol produced beginning in 2009. In the BSM, this is controlled via the Government Policy Input page; the cellulosic ethanol subsidy variable jumps from $\$ 0$ to $\$ 2$, for the first 500M gallons of cellulosic ethanol produced, beginning in 2009. For each gallon of cellulosic ethanol produced, the cellulosic ethanol subsidy is used to calculate the cellulosic ethanol subsidy actual variable, which feeds into attractiveness to build calculations.

\section{Capital Cost Reduction Scenario}

Capital Cost Reduction (model bw070829-Capital.STM). Capital cost reduction subsidies target substantial capital cost associated with the development of a conversion facility. By funding directly a portion of the capital cost, an initiative can reduce the risk of investing in a new industry. The capital cost reduction scenario looks at the impact of a capital subsidy for full scale facilities of $40 \%$ per project up to a total expenditure by the government of $\$ 1.5$ billion, with funds available beginning in 2009. In the BSM, this is controlled via the Government Policy Input page; the Ann Gov Cap $\$ \$ M \$ \$$ yr (for full scale plants) variable jumps from $\$ 0$ to $\$ 1.5$ billion in 2009 . This variable is used to calculate the Gov Project Capital Subsidy (for full scale plants) variable, which feeds into the attractiveness to build calculations.

\section{Combination Operating and Capital Cost Reduction Scenarios}

Grower Payment + Capital Cost Reduction (model \# bw070829-Capital plus Feedstock.STM). This combination scenario explores the joint impact of a feedstock subsidy of $\$ 20 /$ ton in combination with a capital subsidy for full scale plants $(40 \%$ per project; total government expenditure of $\$ 1.5$ billion. The model is modified through the Government Policy Input page as described above for Feedstock and Capital Subsidies.

Production Subsidy + Capital Cost Reduction (model bw070829-Capital plus EtOH.STM). This combination scenario explores the joint impact of a cellulosic ethanol production feedstock subsidy of $\$ 2 /$ gal for the first 500M gallons of cellulosic ethanol produced in combination with a capital subsidy for full scale plants $(40 \%$ per project; total government expenditure of $\$ 1.5$ billion). The model is modified through the Government Policy Input page as described above for Scenarios Cellulosic EtOH and Capital Subsidies.

\section{Results/Discussion}

In the generation of the scenarios presented here, the BSM provides the analyst with an experimental laboratory of sorts. Against a fixed backdrop of assumed relationships, it is possible to conduct controlled experiments in order to better understand how specific policies might facilitate the growth of the industry. Even though the BSM is only in prototype form, analysis can help to clarify issues, identify trade-offs, uncover weaknesses in assumptions, and inform the policy debate. In this case, analysis of scenarios presented here can help in understanding potential growth trajectories and likely volumes of cellulosic ethanol that could be produced in 2017 , as a result of various government initiatives. Additionally, analysis can help to identify potential outcomes 
around biomass feedstock supply and conversion infrastructure. Key performance metrics relevant to this analysis include:

- Potential cellulosic ethanol production

- Cellulosic ethanol production volume

- Cellulosic biomass feedstock requirement

o Full scale cellulosic ethanol facilities on line

- Comparison of policy effectiveness

$\circ$ Cumulative government spending

○ Impact of government spending on cellulosic ethanol production

$\circ$ Impact of government spending on industry capital investment. ${ }^{14}$

\section{Cellulosic Ethanol Production: Base Case and Five Scenarios}

The 2017 cellulosic ethanol production potential ranges from 1.6 to 7.2 billion gallons for the set of policy options evaluated - a significant increase from the $500 \mathrm{M}$ gallons produced in the Base Case. The growth of this capacity through 2017 is shown in Figure 4. The combination of the production subsidy plus capital cost reduction appears to be the most effective option in driving industry growth. The least effective option appears to be the grower payment alone.

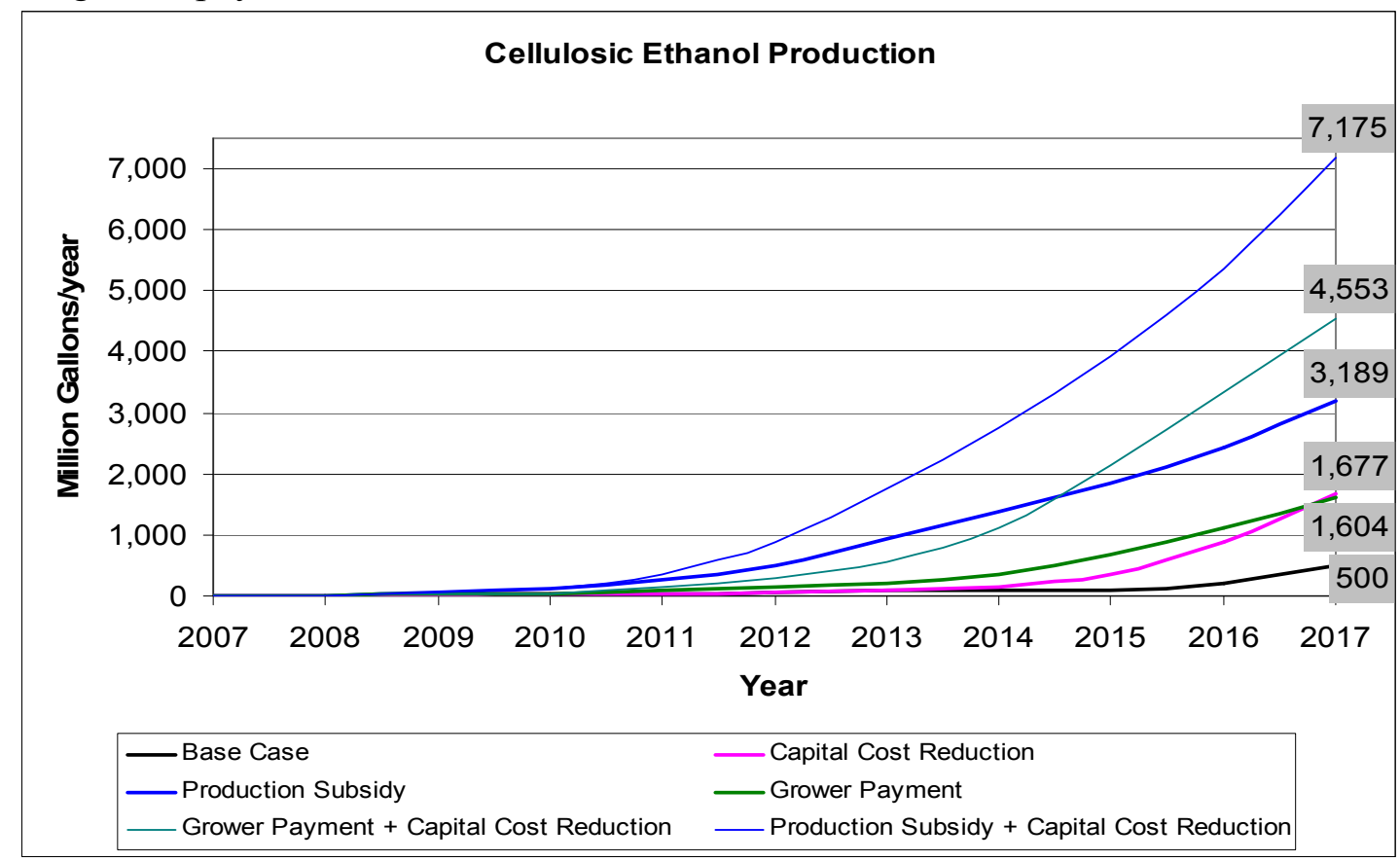

Figure 4. Cellulosic Ethanol Production: Base Case and Five Scenarios

\footnotetext{
${ }^{14}$ The only capital costs currently calculated by the BSM are the capital costs of plants at the demonstration, pioneer, and full scales. The current version of the BSM does not explicitly calculate the costs of feedstock harvesting, storage, and delivery infrastructure nor the costs associated with fuel distribution and infrastructure. See Appendix B for description of model structure.
} 
These curves provide some potential insight into the role of different government initiatives in facilitating growth in the cellulosic ethanol industry over the period of 2007 to 2017. In Figure 4, there are several important things to notice:

- All scenarios lead to higher cellulosic ethanol production in 2017 than in the Base Case.

- Viewed in isolation, the production subsidy initiative yields higher 2017 cellulosic ethanol production than either the capital cost reduction initiative or the grower payment initiative.

- The capital cost reduction scenario, in isolation, appears to yield a higher compounded rate of growth in production in the years 2015-2017 than either the production subsidy initiative or the grower payment initiative.

- The increment in production (relative to the Base Case) from the grower payment + capital cost combination initiative is larger than the sum of the incremental production from grower payment + incremental production from capital cost reduction, suggesting leverage from the combination initiative.

- The incremental production (relative to the Base Case) from the production subsidy + capital cost reduction initiative is larger than the sum of the incremental production from production subsidy + incremental production from capital cost reduction, again suggesting leverage from this combination initiative.

Note that the Base Case and each scenario appear to generate nonlinear behavior. Latent within the model are positive feedbacks that in isolation would tend to underwrite exponential growth in cellulosic production capacity. The rate of growth in the industry can be constrained by investment risk as well as operating costs. By ameliorating these constraints to varying degrees, the scenario initiatives enable growth in production relative to the Base Case.

Generating large quantities of cellulosic ethanol will require significant volumes of biomass feedstocks to supply the substrate for conversion along with construction of many large-scale conversion facilities to produce the ethanol, as summarized below:

- Cellulosic Biomass Feedstock Production Volume. In the current BSM, cellulosic biomass feedstock resources include agricultural and forestry residues and switchgrass. ${ }^{15}$ Potential biomass feedstock production volumes to support the cellulosic ethanol production volumes range from 30 to 146 million dry tons in 2017 (for the grower payment and production subsidy + capital cost reduction scenarios, respectively); 26 million dry tons are required in the Base Case. The maximum total biomass requirement suggested by the BSM is well beyond the

\footnotetext{
${ }^{15}$ Note: Because the feedstock production logic in the BSM is currently undergoing significant modification, the breakout of feedstock type is not included in this analysis.
} 
upper bound of availability of 250 million dry tons by 2017. ${ }^{16}$ (Details for all scenarios are presented at the end of this section in Table 3.)

- Full Scale Cellulosic Ethanol Facilities On-Line. In 2017, the number of full scale (5,000 dry tons/day) cellulosic production facilities on-line ranges from 8 for the grower payment scenario to 37 for the production subsidy + capital cost reduction scenario, in comparison to just two plants for the Base Case. (Details for all scenarios are presented at the end of this section in Table 3.)

\section{Relative Effectiveness of Government Spending in the Scenarios}

To evaluate the effectiveness of different initiatives, it is helpful to (1) compare the cost of initiatives, then (2) compare the impact relative to cost across initiatives. This latter view provides a consistent metric for evaluation. The cumulative government spending by 2017 associated with the initiatives in the scenarios (excluding VEETC and R\&D spending, which is unchanged across all scenarios) is summarized in Table 4. Not surprisingly, the combination scenarios are the most costly; individually, the three subsidies under evaluation require roughly equivalent amounts of government funds.

Table 4. Cost of Initiatives-Cumulative Government Spending in 2017

\begin{tabular}{|l|c|}
\hline \multicolumn{1}{|c|}{ Scenario } & $\begin{array}{c}\text { Cost of Initiative } \\
\text { (Cumulative Government } \\
\text { Spending in 2017) (Million \$) }\end{array}$ \\
\hline Base Case & $\$ 439$ \\
\hline Grower Payment & $\$ 1,552$ \\
\hline Production Subsidy & $\$ 1,568$ \\
\hline Capital Cost Reduction & $\$ 1,671$ \\
\hline Production Subsidy + Capital Cost Reduction & $\$ 2,913$ \\
\hline Grower Payment + Capital Cost Reduction & $\$ 4,384$ \\
\hline
\end{tabular}

Figure 5 shows the effectiveness, relative to government outlay, across scenarios. As this figure illustrates, by 2017 the cumulative government cost for the three policy options considered ranges from $\$ 1.6$ billion for just the Grower Payment to $\$ 4.4$ billion for the Grower Payment + Capital Cost Reduction combination. Figure 5 also shows the cellulosic ethanol produced as a result of each policy option. Note that although the government outlay is greatest for the Grower Payment + Capital Cost Reduction combination, it does not yield the highest volume of cellulosic ethanol. Comparing the ratios of cellulosic ethanol production capacity (gallons) to cumulative government spending in 2017 for each scenario indicates that the combination of the Production Subsidy + Capital Cost Reduction offers the highest return on government investment, with a ratio of almost 2.5:1 (cellulosic ethanol capacity in gallons:cumulative government dollars spent). Second best is the Production Subsidy alone with a ratio of 2:1. The Base Case and other three scenarios are all similar with a ratio of around 1:1.

\footnotetext{
${ }^{16}$ Biomass Multi-Year Program Plan. (November 2007). Office of the Biomass Program, Office of Energy Efficiency and Renewable Energy, U.S. Department of Energy. http://www1.eere.energy.gov/biomass/pdfs/biomass_program_mypp.pdf
} 


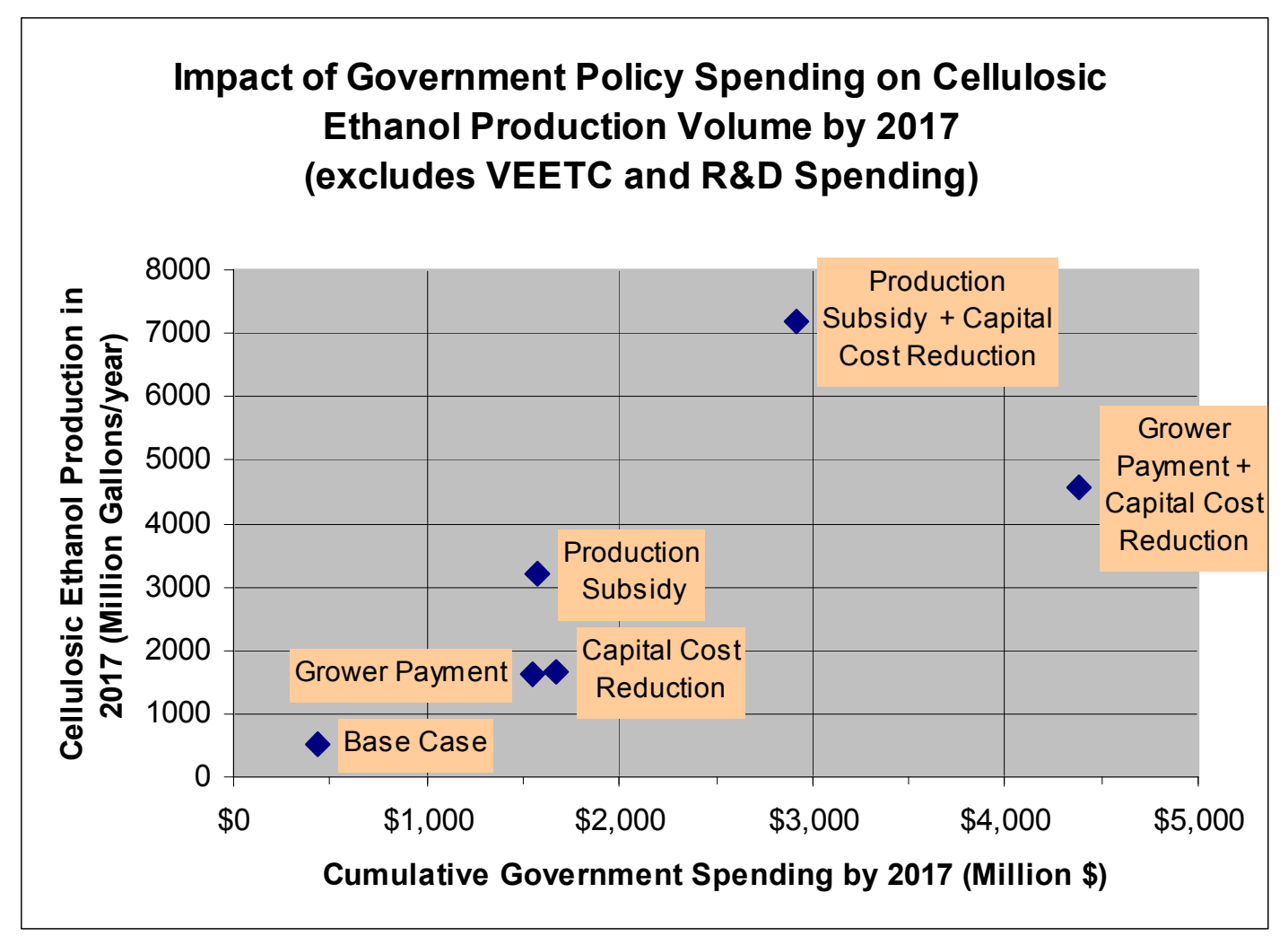

Figure 5. Impact of Cumulative Government Spending on Cellulosic Ethanol Production Volume in 2017 (excludes VEETC and R\&D Spending)

Another way to view the effectiveness of government initiatives is to consider their effectiveness in stimulating private investment. Figure 6 compares government investment (in operating cost reduction and in capital cost reduction) against cumulative private investment across all scenarios. As Figure 6 suggests, the high return on government investment for the Production Subsidy + Capital Cost Reduction combination is reflected in the increased private investment that this scenario appears to motivate. Model results indicate that the Production Subsidy + Capital Cost Reduction motivates private capital investment in cellulosic ethanol production facilities (includes investment for all three scales - demonstration, pioneer, and full scale) more effectively than the other options considered here. For this scenario, each government dollar invested motivates private investment of over $\$ 9$ by 2017. 


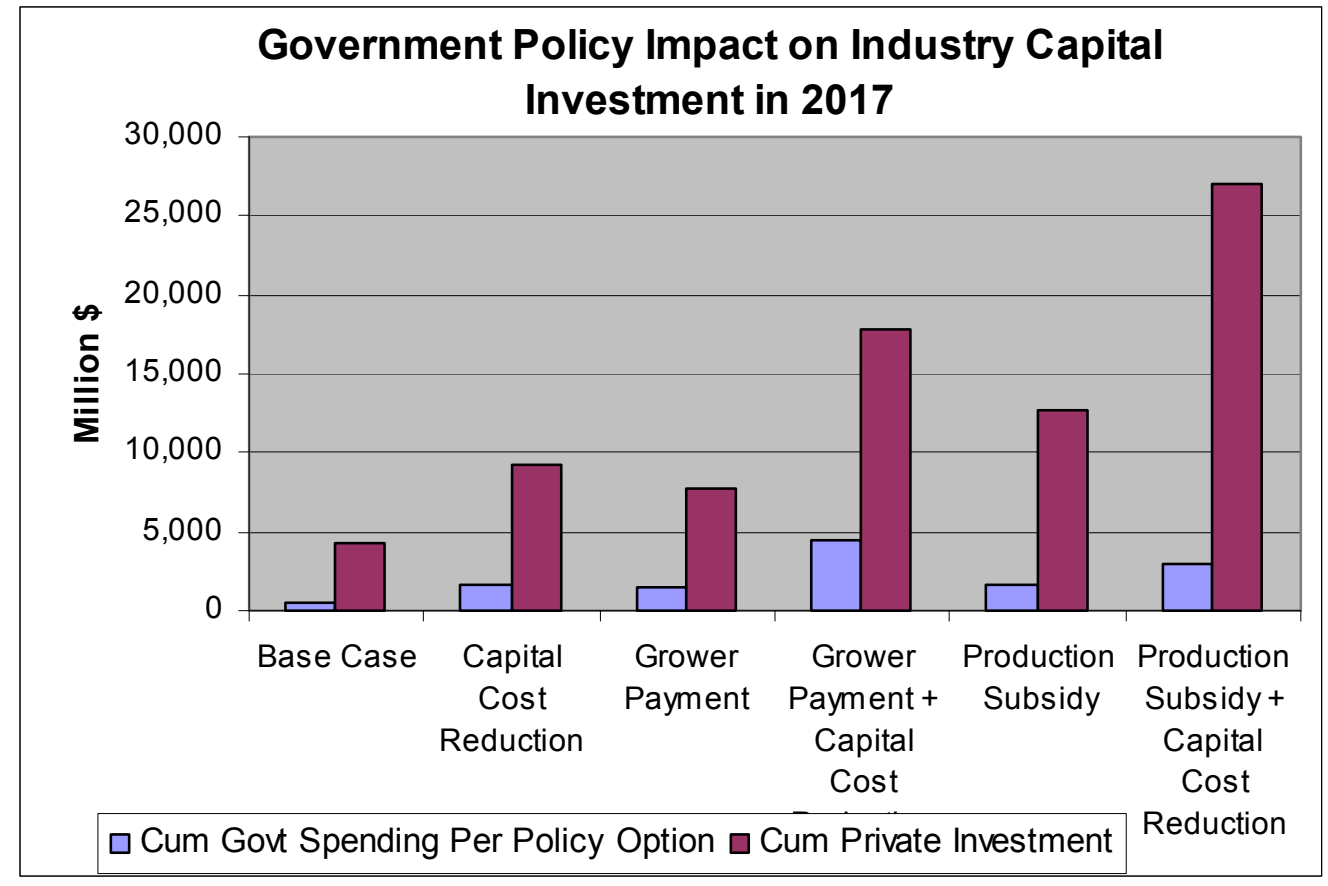

Figure 6. Government Policy Impact on Industry Capital Investment

\section{Key Performance Parameters Across the Biomass-to-Biofuels Supply Chain}

For completeness, the suggested impacts of these proposed government actions in 2017 are summarized for the biomass-to-biofuels supply chain in Table 5. These data are not provided as definitive projections, but rather as preliminary insight into the relative impact of each scenario on the key performance metrics of the supply chain. 
Table 5. Suggested Impact of Policy on BSM Key Performance Parameters Across Biomass-to-Biofuels Supply Chain in 2017

\begin{tabular}{|c|c|c|c|c|c|c|}
\hline & Base Case & $\begin{array}{l}\text { Grower } \\
\text { Payment }\end{array}$ & $\begin{array}{l}\text { Production } \\
\text { Subsidy }\end{array}$ & $\begin{array}{c}\text { Capital Cost } \\
\text { Reduction }\end{array}$ & $\begin{array}{c}\text { Grower } \\
\text { Payment }+ \\
\text { Capital Cost } \\
\text { Reduction } \\
\end{array}$ & \begin{tabular}{|c|} 
Production \\
Subsidy + \\
Capital Cost \\
Reduction \\
\end{tabular} \\
\hline \multicolumn{7}{|c|}{ Biomass Feedstock Production and Logistics } \\
\hline $\begin{array}{c}\text { Agricultural Residues (Million Dry } \\
\text { Tons/year) } \\
\end{array}$ & 23 & 27 & 52 & 38 & 72 & 106 \\
\hline $\begin{array}{c}\text { Forest Residues (Million Dry } \\
\text { Tons/year) }\end{array}$ & 0 & 0 & 6 & 2 & 14 & 25 \\
\hline Switchgrass (Million Dry Tons/year) & 3 & 3 & 8 & 4 & 9 & 14 \\
\hline $\begin{array}{c}\text { Total Biomass Production (Million } \\
\text { Dry Tons/year) }\end{array}$ & 26 & 30 & 66 & 44 & 95 & 146 \\
\hline Feedstock Costs (\$/dry ton) & $\$ 20$ & $\$ 22$ & $\$ 31$ & $\$ 28$ & $\$ 34$ & $\$ 39$ \\
\hline \multicolumn{7}{|c|}{ Biofuels Production } \\
\hline $\begin{array}{c}\text { Cellulosic Ethanol Production } \\
\text { (Million Gallons/year) }\end{array}$ & 500 & 1,604 & 3,189 & 1,677 & 4,553 & 7,175 \\
\hline Number of Full Scale Plants On Line & 2 & 8 & 15 & 9 & 23 & 37 \\
\hline Operating Costs (\$/gallon) & $\$ 0.18$ & $\$ 0.18$ & $\$ 0.18$ & $\$ 0.18$ & $\$ 0.18$ & $\$ 0.18$ \\
\hline $\begin{array}{c}\text { Minimum Ethanol Selling Price } \\
\text { (\$/gallon) }\end{array}$ & $\$ 0.90$ & $\$ 0.90$ & $\$ 0.90$ & $\$ 0.90$ & $\$ 0.90$ & $\$ 0.90$ \\
\hline $\begin{array}{l}\text { Cumulative Private Capital } \\
\text { Spending (Million } \$)^{*}\end{array}$ & $\$ 4,296$ & $\$ 7,789$ & $\$ 12,746$ & $\$ 9,162$ & $\$ 17,840$ & $\$ 27,025$ \\
\hline \multicolumn{7}{|c|}{ Biofuels Distribution and End Use } \\
\hline $\begin{array}{c}\text { Maximum Potential Ethanol } \\
\text { Consumption as E10 in } \\
\text { Conventional Gasoline Vehicles } \\
\text { (Million Gallons/year) }\end{array}$ & 17,260 & 17,260 & 17,260 & 17,260 & 17,260 & 17,260 \\
\hline $\begin{array}{l}\text { Maximum Potential Ethanol } \\
\text { Consumption used as E85 in FFVs } \\
\text { (Million Gallons/year) }\end{array}$ & 27,446 & 27,446 & 27,446 & 27,446 & 27,446 & 27,446 \\
\hline Total FFVs (Million) & 32.7 & 32.7 & 32.7 & 32.7 & 32.7 & 32.7 \\
\hline \multicolumn{7}{|c|}{ Government Investment } \\
\hline $\begin{array}{c}\text { Cumulative Government Spending } \\
(\text { Million } \$)^{* *}\end{array}$ & $\$ 24,688$ & $\$ 25,802$ & $\$ 25,817$ & $\$ 25,920$ & $\$ 28,634$ & $\$ 24,389$ \\
\hline $\begin{array}{l}\text { Cumulative Government Spending-- } \\
\text { excluding VEETC and R\&D (Million } \\
\text { \$) }\end{array}$ & $\$ 439$ & $\$ 1,552$ & $\$ 1,568$ & $\$ 1,671$ & $\$ 4,384$ & $\$ 2,913$ \\
\hline Model Number & \begin{tabular}{|c|} 
bw070829-base- \\
sp.STM
\end{tabular} & \begin{tabular}{|c|} 
bw070829- \\
Feedstock.STM
\end{tabular} & \begin{tabular}{|c|} 
bw070829-EtOH \\
Subsidy.STM
\end{tabular} & $\begin{array}{l}\text { bw070829- } \\
\text { Capital.STM }\end{array}$ & \begin{tabular}{|c|} 
Capital plus \\
Feedstock.STM
\end{tabular} & $\begin{array}{l}\text { Capital plus } \\
\text { EtOH.STM }\end{array}$ \\
\hline
\end{tabular}

\section{Summary/Conclusions}

It is critical to remember that the BSM is a prototype model that is still being developed and, as such, its results must be interpreted and applied with caution. The analysis results presented here are not predictions, but plausible scenarios that can help policy makers to envision in broad terms potential future conditions.

The scenarios here focused on a set of government initiatives, in isolation and in combination, targeted at reduction in operating costs and/or reduction in capital cost. The analysis viewed the five resultant scenarios in terms of their performance through 2017. All options were evaluated in the context of influencing the investment decision to build full-scale cellulosic ethanol production facilities. The analysis suggests that the policies considered here - feedstock grower payment, cellulosic ethanol production subsidy, and 
capital subsidy for construction of full-scale cellulosic ethanol production facilities - can motivate production of between 1.6 and 7.2 billion gallons of cellulosic ethanol production by 2017 .

To produce these volumes of cellulosic ethanol, the BSM results indicate that a cumulative government investment on the order of $\$ 1.5$ to $\$ 4.4$ billion will be needed. (Note that this level of investment is dwarfed by the current VEETC, which the model suggests will cost taxpayers over $\$ 23$ billion by the time it expires in 2010.)

The scenarios presented here suggests that government initiatives can be used to "prime the pump," reducing investment risk and initial operating cost, thus enabling the new industry to grow to the point at which it has become self-sustaining.

For this analysis, which focuses on the deployment of cellulosic ethanol production facilities, the preferred policies and incentives are those with the highest leverage to close the gap between the investor required rate of investment (ROI) and the expected ROI (for commercial plants) until industrial experience catches up. The synergies of combining the capital and operating cost subsidies appear to provide the highest leverage in triggering the beginnings of a sustainable bioindustry.

\section{Recommendations/Next Steps}

The current Base Case BSM should be recognized as a preliminary model. The model structure and data were reviewed in October 2006 by experts in agriculture, ethanol processing, investment, and vehicle manufacturing. ${ }^{17}$ The next steps are focused on developing a more robust representation of the dynamics at play in the transition to a future cellulosic ethanol industry.

In the short term, modifications and refinements in response to the BSM review are already in progress, with a new base case-BSM v.2 - scheduled for completion in 2008. Once the revised model is finalized and vetted with the standing BSM review committee (established as part of the October 2006 workshop), the new base case will be documented in detail. In addition, the policy scenarios investigated in this analysis will be revisited to determine the impacts, if any, on the model results. The analysis could then be expanded to investigate the optimum timing of different types of subsidies, the sensitivities around the magnitude of each type of subsidy (along with evaluation of other policy options under consideration including crop insurance programs for cellulosic ethanol producers), loan guarantees for commercial-scale cellulosic ethanol production facilities, and carbon-based incentives for renewable fuels production among others.

The following enhancements to the model are planned for completion over the next two years:

\footnotetext{
${ }^{17}$ Biomass Scenario Model Workshop Results. (October 25, 2006). Office of the Biomass Program, Office of Energy Efficiency and Renewable Energy, U.S. Department of Energy. http://30x30workshop.biomass.govtools.us/documents/061106ScenarioModelWorkshopReport.pdf
} 
- Feedstock Production and Logistics

o Incorporate high-level regionalized feedstock production data to facilitate analysis of regional differences

o Incorporate additional feedstocks data (starch product, herbaceous energy crop, herbaceous residue, woody energy crop, forestry residue, urban wood waste)

o Improve representation of land allocation logic, allowing for multiple uses of agricultural land (i.e., competition between annual crops and other agricultural uses)

o Enhance representation of economics associated with feedstock logistics

- Biomass Conversion

o Expand model to include additional conversion technologies (starch; starch

+ fiber; starch + biochemical; biochemical; thermochemical; combination)

$\circ$ Enhance representation of investor behavior (venture capitalists; big vs. small company)

- Biofuels Distribution and End Use

○ Incorporate high-level regional desegregation regarding concentration of automobiles across the U.S. to facilitate analysis of regional differences

o Develop structure to capture evolution of system to connect ethanol production to fuel use (including logic of greenfield vs. retrofit options for pipelines, dispensing stations, etc.)

o Incorporate multiple distribution modalities (truck, rail, barge, pipeline) and allow for greenfield vs. retrofit of pipelines

- Petroleum Industry Representation

○ Incorporate simple global petroleum supply/demand dynamics, including key oil stocks, refinery capacity, and global petroleum demand scenarios.

In the longer term, additional aspects of the dynamics surrounding the transition from petroleum- to biomass-based fuels could be investigated through the following model enhancements/expansions:

- Future energy scenarios that reflect global competition for oil more aggressively than DOE-EIA projections

- Improved characterization of the investment required to advance technologies from RD\&D to the point of viable commercialization

- Ability to look at impacts of failed RD\&D and ethanol production facilities (current model assumes 100\% success)

- Additional biofuels capabilities beyond ethanol

- Competition from other alternative fuels (e.g., coal-to-liquids) 
- Addition of forestry land allocation logic

- Environmental implications/aspects costs and benefits: water, GHG, sustainability

- International/global fuel market impacts

- Optimum timing of government policies and incentives. 


\section{Appendix A: An Overview of Symbology Used by the STELLA Modeling Tool}

The system dynamics framework and the STELLA software tool were chosen for the BSM development effort because of their ability to address systems problems. The software, developed by ISEE Systems, Inc. (www.iseesystems.com) provides a simple, yet powerful visual language for representing and simulating dynamic systems and processes, thus making the system dynamics framework accessible as a desktop tool for analysts and policy makers.

STELLA uses the symbolic language of system dynamics to represent dynamic systems and processes. This language is composed of a small set of primitives. These building blocks for the language are summarized in Table A-1.

Table A-1. Primitives of the system dynamics language as implemented in the STELLA software

\begin{tabular}{|c|c|c|c|c|}
\hline Symbol & Name & Purpose & $\begin{array}{l}\text { Mathematical } \\
\text { Analog }\end{array}$ & $\begin{array}{l}\text { Language/ } \\
\text { Grammar } \\
\text { Analog }\end{array}$ \\
\hline & Stock & $\begin{array}{l}\text { Accumulate "stuff" } \\
\text { (like a bathtub } \\
\text { accumulates water) }\end{array}$ & $\begin{array}{l}\text { State variable } \\
\text { time integration }\end{array}$ & Noun \\
\hline & Flow & $\begin{array}{l}\text { Fill or deplete } \\
\text { accumulations over } \\
\text { time }\end{array}$ & Time derivative & Verb \\
\hline 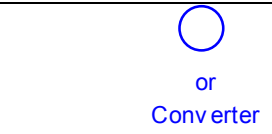 & Converters & $\begin{array}{l}\text { Input/output } \\
\text { relationship; decision } \\
\text { rule; model constant }\end{array}$ & $\begin{array}{l}\text { Auxiliary } \\
\text { equation }\end{array}$ & $\begin{array}{l}\text { Adjectives and } \\
\text { adverbs }\end{array}$ \\
\hline$b$ & $\begin{array}{l}\text { Connector, } \\
\text { wire }\end{array}$ & $\begin{array}{l}\text { Connect inputs to } \\
\text { outputs. Show } \\
\text { dependency } \\
\text { relationships }\end{array}$ & $f()$ & Conjunction \\
\hline
\end{tabular}

Together, these language primitives make it possible to create models of rich dynamic complexity. Often these models are based on a simple accounting structure that captures key physical relationships in the system of interest. A simple example of such physical relationships is shown in Figure A-1. In this structure, stocks and flows are used to account for the distribution of crops in switchgrass and in other uses. Flows capture the movement from other uses to switchgrass as well as the reverting of switchgrass back to other uses. Converters and connectors are used to capture the logic behind the movement into switchgrass (farmers move land to switchgrass based on its economic attractiveness relative to other uses), as well as the logic controlling the movement of land from switchgrass back to other uses (reversion is proportional to the useful economic lifetime switchgrass). 


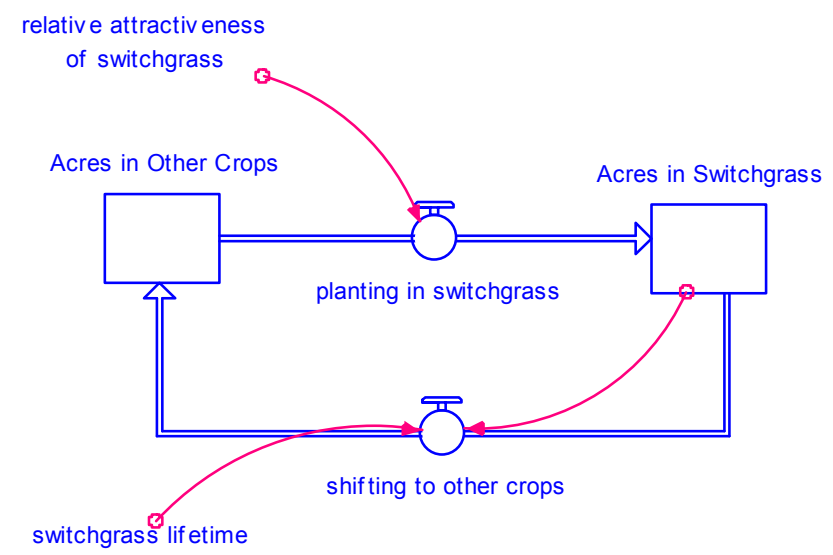

Figure A-1. Simple Structure Accounting for Allocation of Land Between Switchgrass and Other Uses 


\section{Appendix B: Structural Description of the Biomass Scenario Model (BSM)}

\section{Introduction}

From a conceptual perspective, the BSM is organized around five modules, each of which corresponds to a stage in the biomass-to-biofuels supply chain. This supply chain is shown below, in Figure B-1:

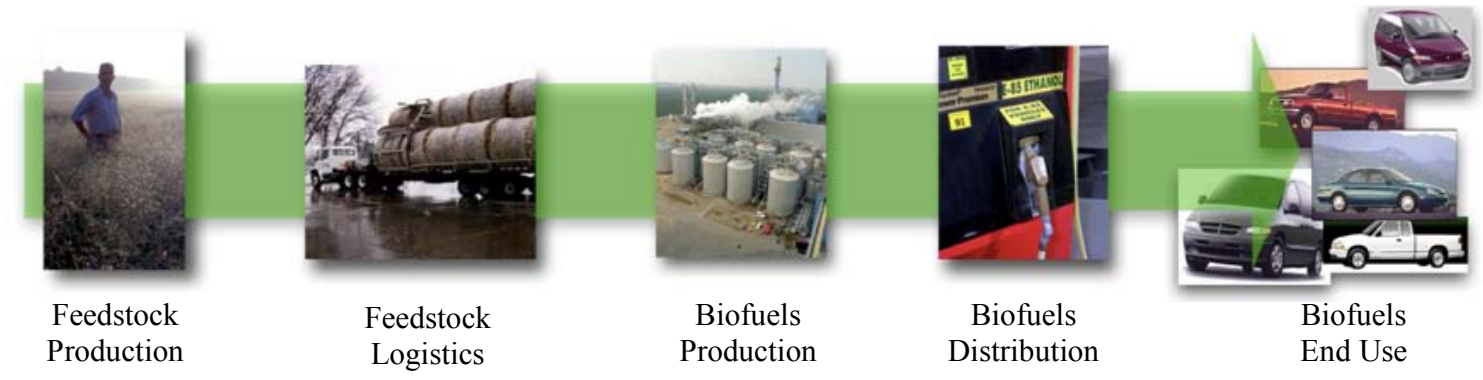

Figure B-1. The Biomass-to-Biofuels Supply Chain

Because the model is a prototype, not all modules suggested by the supply chain are represented in deep detail within the BSM. In particular, biofuels distribution from point of production to point of use is not represented within the model. For the remaining modules, a comprehensive description is provided from the perspective of:

- Module purpose and approach

- Key module outputs and inputs

- The structure, logic, and decision rules embedded into the module

- Policy levers and scenario variables that impact the module.

\section{Feedstock Production Module}

The feedstock production module serves to provide a basis for the production of cellulosic feedstocks within BSM, respecting the constraints imposed by the agricultural land base in a manner consistent with economics. In its approach, the module is very simple. Specifically:

- The module considers a single dedicated energy crop (switchgrass). This energy crop competes against an amalgam of "all other" crops.

- Existing analyses (POLYSYS) are used to generate supply curves of cellulosic agriculture residues and forest residues.

- To manage detail complexity, the agriculture system is modeled as a single aggregated region.

- Two land types are considered: prime and marginal agricultural land. Marginal land corresponds roughly with Conservation Reserve Program (CRP) land, while prime land corresponds with USDA's "Cropland Used for Crops" classification. 


\section{Key Performance Indicators, Outputs, and Inputs}

Table B-1 summarizes key performance indicators, module outputs (to other modules), and module inputs (from other modules and from policy levers/scenarios). Because the Feedstock Production module is at the beginning of the supply chain, most of its interaction is with the Biofuels Production module.

Table B-1. KPIs, Outputs, and Inputs Associated with Feedstock Production Module

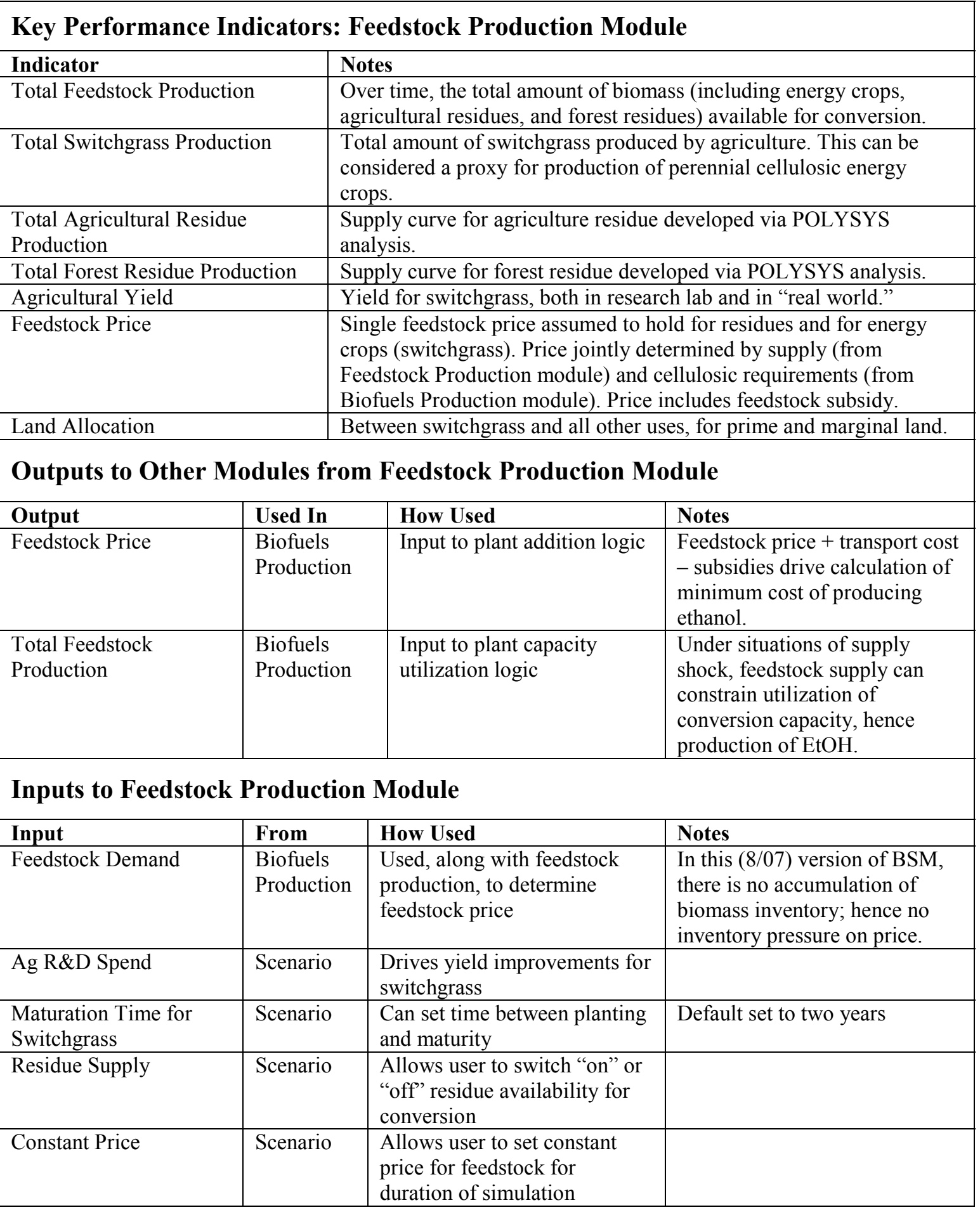


Structure, Logic, and Decision Rules for the Feedstock Production Module The Feedstock Production module functions as a framework for generating cellulosic feedstocks, both from dedicated crops (switchgrass) and from residues. Figure B-2 presents a highly simplified representation of the framework and the key feedback relationships that drive behavior within the Feedstock Production module.
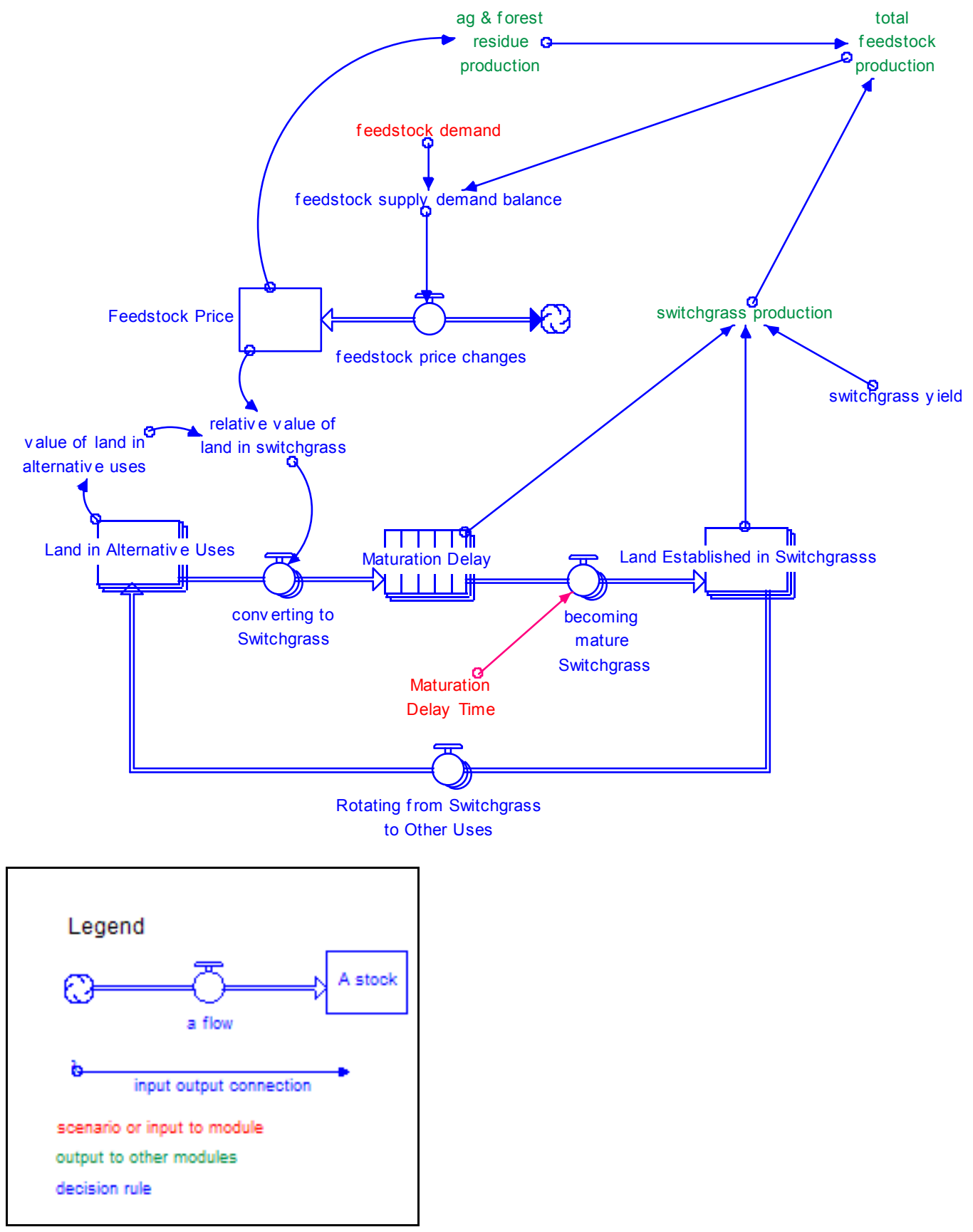

Figure B-2. Simplified view land allocation and feedstock production

As the diagram suggests, there are two fundamental components to the supply of cellulosics. The first component is residues from agriculture and forestry. These residues 
are provided as a function of feedstock price. As price increases, quantity supplied follows suit. The supply curves for both agricultural residues and forest residues were developed using POLYSYS. ${ }^{18}$

The second component of cellulosic supply is driven by the quantity of land in switchgrass, represented by the maturation delay and the land established in switchgrass. The switchgrass yield per acre is applied to the acres in switchgrass to generate switchgrass production. Note that land that is in the maturation delay is assumed to have a lower yield than mature land.

An important feature of feedstock supply is the structure that constrains overall production to the total amount of land in the system. As shown in the diagram, land moves "other uses" through the maturation delay into fully productive switchgrass and then back again to other uses. Land cannot be in switchgrass indefinitely. In the model it is assumed that land spends 10 years on average in switchgrass before rotating back into other uses. Because both land bases represented in the module — prime and marginal — are conserved, the module ensures that there are no free lunches from a land availability perspective.

The movement of land is driven by a simple pricing mechanism. In the model, land is assumed to go to its highest-valued use. Here's how the pricing/land allocation system works:

- Price drives the quantity supplied for residues.

- Price also provides a basis for farmer calculation of net revenue per acre for switchgrass, for both prime and marginal land.

- Farmers compare revenue per acre for switchgrass against expected revenue per acre for land in other uses. As relative value of land in switchgrass rises, land tends to move toward use in switchgrass.

- As land moves toward switchgrass, the value of land in alternative uses tends to increase. This in turn slows the movement of land away from other uses toward switchgrass.

- Specific sensitivities are assumed to differ for prime and marginal land. Marginal land in other uses is assumed to move into switchgrass at lower feedstock price. Its relative value cost is assumed to rise less quickly as it is moved into switchgrass.

- Price changes are driven by imbalances between demand for feedstock (from the Biofuels Production module) and the supply of feedstock (both switchgrass and residues).

\footnotetext{
${ }^{18}$ De La Torre Ugarte, Daniel G. and Daryll E. Ray (2000) Biomass and Bioenergy Applications of the POLYSYS Modeling Framework, Biomass and Bioenergy, 4 (3):118. http://apacweb.ag.utk.edu/polysys.html
} 
When woven together, these relationships result in dynamics that work to equilibrate supply and demand of feedstocks as the industry evolves over time.

A second portion of the feedstock supply module captures the relationships between R\&D spending and yield improvements. Figure B-3 provides a high-level view into these relationships.

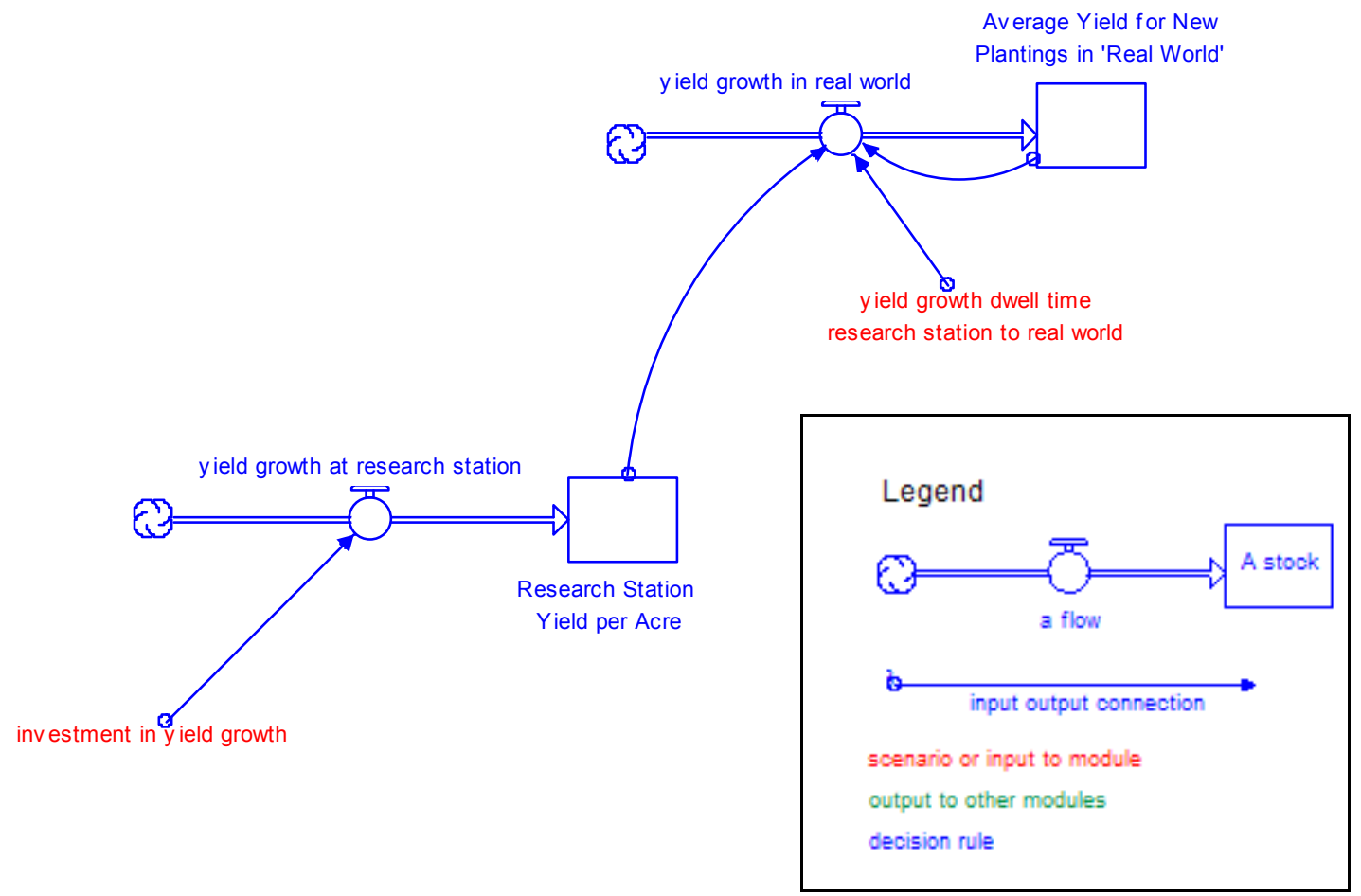

Figure B-3. Simplified structure for tracking yield growth in switchgrass

This structure is a simple representation of the agricultural research process, as well as the process by which improvements in crop yields make their way from a research setting into the real world. Using corn as an analog, the model relates yearly investment in yield growth to the growth in yield at the level of agricultural research stations. Yield growth is assumed to be exponential at first, and then linear after yield has reached a (user-defined) threshold level. After a "dwell" time (again, set by the user), yields change for new plantings of switchgrass in the real world. These yields are then tracked for land as it works its way through the cycling between alternative uses and switchgrass.

Feedstock Logistics Module. The feedstock logistics module accounts for the cost associated with moving biomass feedstock from point of production (i.e., "farm-gate") to point of conversion (i.e., "plant-gate"). Rather than model alternative infrastructure/transport systems, truck transport was assumed for the purpose of calculating cost of transport. 
Key Performance Indicators, Outputs, and Inputs

Table B-2 summarizes key performance indicators, module outputs (to other modules), and module inputs (from other modules and from policy levers/scenarios). As suggested by Table B-2, this stage in the supply chain is represented simply.

Table B-2. KPIs, Outputs, and Inputs Associated with Feedstock Logistics Module

\begin{tabular}{|c|c|c|c|}
\hline \multicolumn{4}{|c|}{ Key Performance Indicators: Feedstock Logistics Module } \\
\hline Indicator & \multicolumn{3}{|l|}{ Notes } \\
\hline Transport charge & \multicolumn{3}{|c|}{ Calculated for each plant size (demonstration, pioneer, full scale) } \\
\hline \multicolumn{4}{|c|}{ Outputs to Other Modules from Feedstock Logistics Module } \\
\hline Output & Used in & How Used & Notes \\
\hline Transport charge & Biofuels Production & $\begin{array}{l}\text { Combined with farm gate } \\
\text { cost per ton to drive } \\
\text { overall feedstock cost per } \\
\text { ton }\end{array}$ & $\begin{array}{l}\text { Calculated for each plant } \\
\text { size (demonstration, } \\
\text { pioneer, full scale) }\end{array}$ \\
\hline \multicolumn{4}{|c|}{ Inputs to Feedstock Logistics Module } \\
\hline Input & From & How Used & Notes \\
\hline $\begin{array}{l}\text { Average plant input } \\
\text { capacity in tons per } \\
\text { day }\end{array}$ & Biofuels Production & $\begin{array}{l}\text { Used to calculate average } \\
\text { distance to plant }\end{array}$ & $\begin{array}{l}\text { Calculated for each plant } \\
\text { size (demonstration, } \\
\text { pioneer, full scale) }\end{array}$ \\
\hline $\begin{array}{l}\text { Average days per year } \\
\text { online }\end{array}$ & Biofuels Production & $\begin{array}{l}\text { Used to calculate average } \\
\text { distance to plant }\end{array}$ & \\
\hline $\begin{array}{l}\text { Average switchgrass } \\
\text { yield }\end{array}$ & $\begin{array}{l}\text { Feedstock } \\
\text { Production }\end{array}$ & $\begin{array}{l}\text { Used to calculate average } \\
\text { distance to plant }\end{array}$ & \\
\hline $\begin{array}{l}\text { Fraction of land } \\
\text { surrounding plant in } \\
\text { switchgrass }\end{array}$ & Assumption/Scenario & $\begin{array}{l}\text { Used to calculate average } \\
\text { distance to plant }\end{array}$ & \\
\hline Winding factor & Assumption/Scenario & $\begin{array}{l}\text { Used to calculate transport } \\
\text { charge }\end{array}$ & $\begin{array}{l}\text { Accounts for road windage } \\
\text { from field to plant }\end{array}$ \\
\hline $\begin{array}{l}\text { Fixed transport } \\
\text { charge/ton }\end{array}$ & Scenario & $\begin{array}{l}\text { Used to calculate transport } \\
\text { charge }\end{array}$ & $\begin{array}{l}\text { Total cost is sum of fixed } \\
\text { and variable costs }\end{array}$ \\
\hline Cost per ton-mile & Scenario & $\begin{array}{l}\text { Used to calculate transport } \\
\text { charge }\end{array}$ & $\begin{array}{l}\text { Total cost is sum of fixed } \\
\text { and variable costs }\end{array}$ \\
\hline
\end{tabular}

Structure, Logic, and Decision Rules for the Feedstock Logistics Module The essential logic for the feedstock transport cost calculation is shown in Figure B-4. 


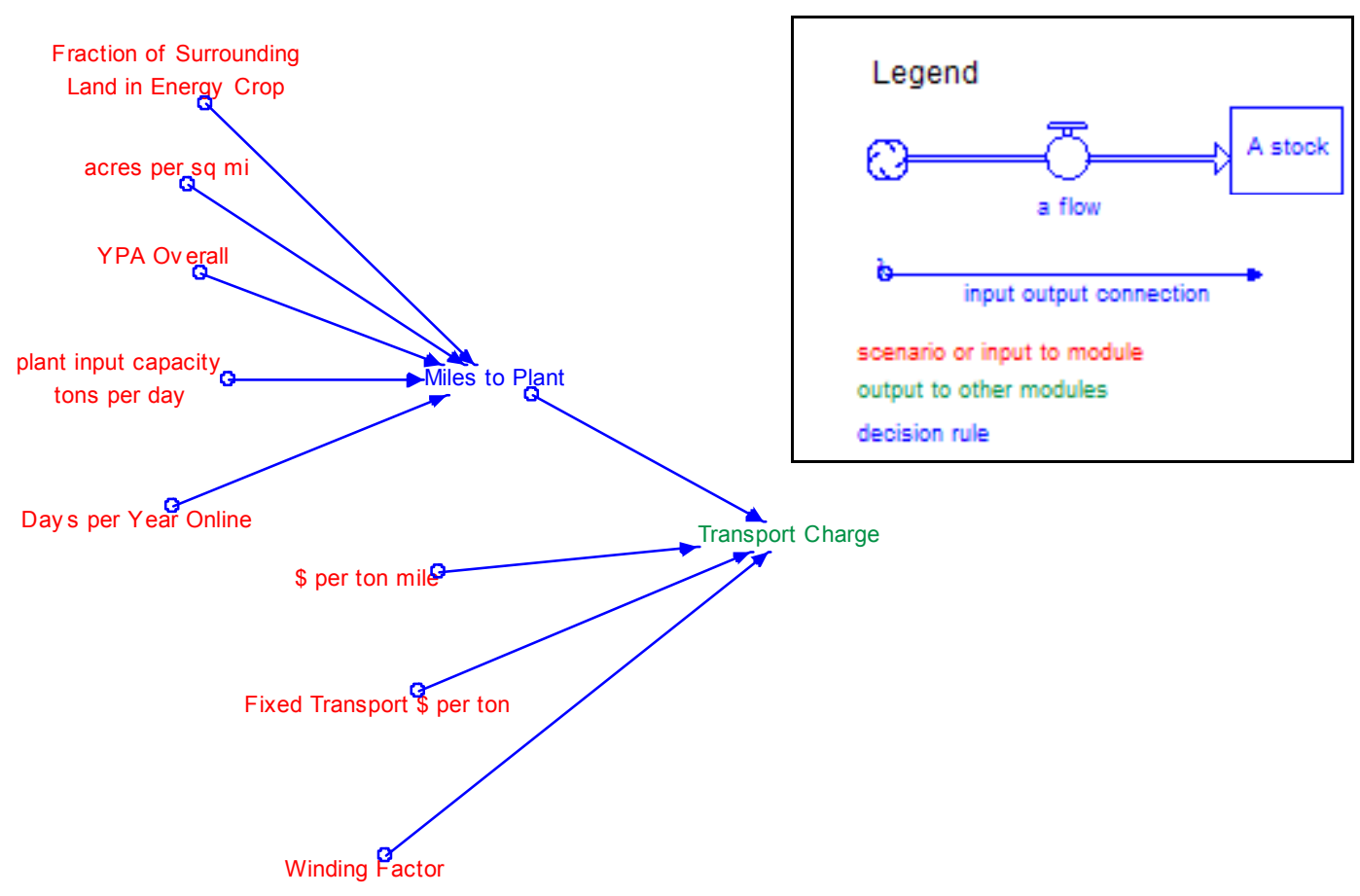

Figure B-4. Inputs and Outputs Associated with Feedstock Logistics Module

As Figure B-4 suggests, transport charge has a fixed and a variable component. Variable costs are determined by applying a winding factor to the product of cost per ton-mile and the radial distance from farm to plant. Average distance to plant is calculated by assuming that feedstock production is distributed in a space centered on the plant. Plant feedstock requirements, agricultural yield, and an assumption about the amount of land surround the plant that is dedicated to energy crops, serve as input to a calculation of the average distance required to transport feedstock from farm to pant.

This structure is very simple and consistent with the prototype nature of BSM. In subsequent versions of the BSM, the transport module will see significant enrichments and enhancements.

\section{Biofuels Production Module}

As the name suggests, the Biofuels Production module is concerned with the conversion of feedstocks into ethanol for fuel. There are three focal points to the Biofuels Production module logic:

- Representing the logic associated with the decision to add new plants to the system

- Tracking key attributes (number and yield) of demonstration-scale, pioneer-scale and full-scale plants as they move through stages of design/construction, startup, and fully on-line

- Providing a framework for the capture of plant yield dynamics - at the precommercial and post-commercial levels. 
Key Performance Indicators, Outputs, and Inputs

Table B-3 summarizes key performance indicators, module outputs (to other modules), and module inputs (from other modules and from policy levers/scenarios).

Table B-3. KPIs, Outputs, and Inputs Associated with Biofuels Production Module

\begin{tabular}{|l|l|}
\hline \multicolumn{2}{|l|}{ Key Performance Indicators: Biofuels Production Module } \\
\hline Indicator & Notes \\
\hline Total EtOH production & Includes corn and cellulosic \\
\hline Corn EtOH production & \\
\hline $\begin{array}{l}\text { Cellulosic EtOH } \\
\text { production }\end{array}$ & \\
\hline Number of on-line plants & Broken down by scales (demonstration, pioneer, and full scale) \\
\hline $\begin{array}{l}\text { Minimum ethanol selling } \\
\text { price }\end{array}$ & $\begin{array}{l}\text { Given current state of system (including economic "drivers" such as \% } \\
\text { equity financing, required rate of return, taxes, subsidies, co-product credits, } \\
\text { etc.) determines the minimum price at which ethanol can be sold }\end{array}$ \\
\hline $\begin{array}{l}\text { Cumulative capital } \\
\text { spending on plants }\end{array}$ & \begin{tabular}{l} 
Includes both private and government capital \\
\hline $\begin{array}{l}\text { Cumulative government } \\
\text { EtOH subsidy }\end{array}$
\end{tabular} \\
\hline $\begin{array}{l}\text { Cumulative government } \\
\text { feedstock subsidy }\end{array}$ & \\
\hline $\begin{array}{l}\text { Cumulative government } \\
\text { R\&D spend }\end{array}$ & \\
\hline
\end{tabular}

\section{Outputs to Other Modules from Biofuels Production Module}

\begin{tabular}{|l|l|l|l|}
\hline Output & Used In & How Used & Notes \\
\hline EtOH supply & $\begin{array}{l}\text { Biofuels } \\
\text { End Use }\end{array}$ & $\begin{array}{l}\text { Used to calculate "filling" of } \\
\text { E10, E85 markets }\end{array}$ & \\
\hline Feedstock demand & $\begin{array}{l}\text { Feedstock } \\
\text { Production }\end{array}$ & $\begin{array}{l}\text { Used in conjunction with } \\
\text { feedstock supply to determine } \\
\text { price movement }\end{array}$ & \\
\hline $\begin{array}{l}\text { Average plant input } \\
\text { capacity in tons per day }\end{array}$ & $\begin{array}{l}\text { Feedstock } \\
\text { Logistics }\end{array}$ & $\begin{array}{l}\text { Used to calculate average } \\
\text { distance to plant }\end{array}$ & $\begin{array}{l}\text { Calculated for each plant size } \\
\text { (demonstration, pioneer, full } \\
\text { scale) }\end{array}$ \\
\hline $\begin{array}{l}\text { Average days per year } \\
\text { online }\end{array}$ & $\begin{array}{l}\text { Feedstock } \\
\text { Logistics }\end{array}$ & $\begin{array}{l}\text { Used to calculate average } \\
\text { distance to plant }\end{array}$ & \\
\hline
\end{tabular}

\section{Inputs to Biofuels Production Module}

\begin{tabular}{|c|c|c|c|}
\hline Input & From & How Used & Notes \\
\hline Potential EtOH demand & $\begin{array}{l}\text { Biofuels } \\
\text { End Use }\end{array}$ & Input to plant addition logic & $\begin{array}{l}\text { As EtOH market reaches } \\
\text { saturation, growth in industry } \\
\text { slows. Potential demand broken } \\
\text { into E10 and E85 components }\end{array}$ \\
\hline Gasoline price & $\begin{array}{l}\text { Biofuels } \\
\text { End Use }\end{array}$ & Input to plant addition logic & $\begin{array}{l}\text { Attractiveness of new plant } \\
\text { additions is constrained by } \\
\text { relative price of EtOH and } \\
\text { gasoline (BTU equivalency } \\
\text { basis) }\end{array}$ \\
\hline Transportation cost & $\begin{array}{l}\text { Feedstock } \\
\text { Logistics }\end{array}$ & Input to plant addition logic & \\
\hline Project subsidy & Scenario & $\begin{array}{l}\text { Set annual spend, max } \% \text { of } \\
\text { project subsidized, and max }\end{array}$ & $\begin{array}{l}\text { Can independently set levers for } \\
\text { Demonstration, pioneer, and }\end{array}$ \\
\hline
\end{tabular}




\begin{tabular}{|c|c|c|c|}
\hline & & $\begin{array}{l}\text { subsidy per project by project } \\
\text { scale }\end{array}$ & full scale plants \\
\hline $\begin{array}{l}\text { Government pre- } \\
\text { commercial R\&D } \\
\text { spending }\end{array}$ & Scenario & $\begin{array}{l}\text { Set spending at fundamental } \\
\text { research and at pilot plant } \\
\text { level }\end{array}$ & $\begin{array}{l}\text { Decreases risk at "next" level of } \\
\text { scale. Moves system more } \\
\text { quickly to "mature capacity" } \\
\text { yields }\end{array}$ \\
\hline Ethanol subsidy & Scenario & $\begin{array}{l}\text { Makes all ethanol more } \\
\text { attractive to producers }\end{array}$ & \\
\hline $\begin{array}{l}\text { Cellulose-specific } \\
\text { subsidy }\end{array}$ & Scenario & $\begin{array}{l}\text { Makes cellulosic ethanol more } \\
\text { attractive to producers }\end{array}$ & $\begin{array}{l}\text { Active only when there is no } \\
\text { general ethanol subsidy }\end{array}$ \\
\hline Feedstock subsidy & Scenario & $\begin{array}{l}\text { Lowers cost of delivered } \\
\text { feedstock (relative to price } \\
\text { received by feedstock } \\
\text { producers) }\end{array}$ & \\
\hline $\begin{array}{l}\text { Feedstock captive/free } \\
\text { switches }\end{array}$ & Scenario & $\begin{array}{l}\text { Make (unsubsidized) delivered } \\
\text { cost of feedstock zero }\end{array}$ & $\begin{array}{l}\text { Limited to first } 2 \text { million } \\
\text { tons/yr of industry input } \\
\text { capacity }\end{array}$ \\
\hline Financial parameters & Scenario & $\begin{array}{l}\text { Set requirements for equity } \\
\text { return, debt interest rate, tax } \\
\text { rate, \% plant financing by } \\
\text { plant scale }\end{array}$ & \\
\hline Investor parameters & Scenario & $\begin{array}{l}\text { Set investor type (aggressive, } \\
\text { moderate, conservative), } \\
\text { enable venture capitalists }\end{array}$ & \\
\hline $\begin{array}{l}\text { Corn ethanol industry } \\
\text { parameters }\end{array}$ & Scenario & $\begin{array}{l}\text { Set corn grain price, capital } \\
\text { cost of corn ethanol plants, } \\
\text { max corn ethanol plants }\end{array}$ & $\begin{array}{l}\text { Rudimentary corn ethanol } \\
\text { industry generates supply of } \\
\text { corn ethanol; not tightly } \\
\text { integrated with rest of biofuels } \\
\text { production module }\end{array}$ \\
\hline
\end{tabular}

\section{Structure, Logic, and Decision Rules for the Biofuels Production Module}

There are three fundamental components to the Biofuels Production module. One component represents the decision rules associated with the addition of new plants to the system. The second component tracks key attributes of plants (number, size, and conversion yield) as they move through design and construction, to startup, to fully online status. The third component considers pre-commercial and post-commercial R\&D activities as they relate to yield. Consider each in turn.

Decision rules associated with plant addition: Figure B-5 presents a highly simplified representation of the decision logic used to drive the addition of plants to the industry. 


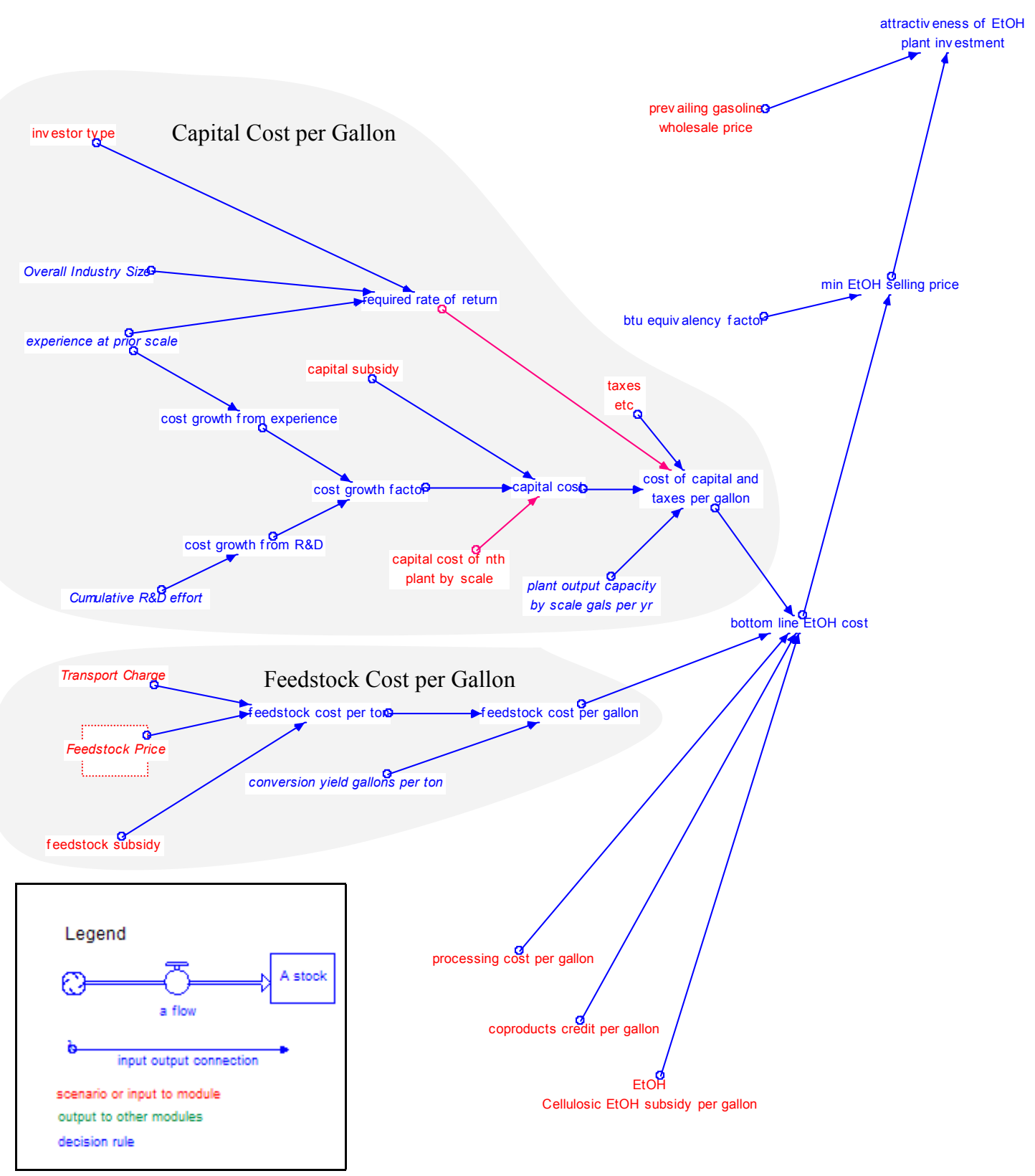

Figure B-5. Simplified View of Logic Determining Attractiveness of EtOH Plant Investment

As the diagram suggests, the fundamental nature of the decision logic involves determination of the attractiveness of an $\mathrm{EtOH}$ plant investment. This is done by comparing the minimum selling price for ethanol, after accounting for volumetric BTU differences as well as various subsidies and credits, against the cost of the highest-valued alternative (corn ethanol when RFS is being "filled", wholesale gasoline otherwise). Lower relative price for ethanol implies higher attractiveness, and hence a more rapid investment. Higher relative price means no incentive to invest. Within the model (but not shown in the diagram), an arrayed structure captures the investment decision at each of three plant scales: demonstration, pioneer, and full scale. 
Within the model, minimum selling price for ethanol is determined by multiple factors. These include:

- Product subsidies (ethanol, or cellulosic ethanol)

- Credits for co-product (protein, fuel, power)

- Plant processing cost per gallon

- Feedstock cost per gallon. This in turn is determined by:

o Delivered feedstock cost (feedstock price, net of transportation and subsidies) on a per-ton basis

o Plant conversion yield (converts cost per ton to cost per gallon)

- The capital cost of the contemplated plant, apportioned on a per-gallon basis. This capital cost per gallon is driven by:

o Estimated (scale-dependent) capital cost of the plant

$\circ$ The production or output capacity of the plant

$\circ$ The required rate of return for the plant

o Taxes and other standard financial variables.

For both the estimated capital cost of the plant and the required rate of return, the state of industry evolution is of critical importance. First, the minimum capital cost at each scale is driven fundamentally by the cost of the "nth" plant at that scale. To this cost at each scale is applied a capital cost growth factor, which itself is determined jointly by cumulative R\&D effort and experience at prior scales. In effect, if the industry has not "done its homework" in R\&D and in smaller scale efforts, the capital cost for the contemplated plant will be significantly higher.

Second, the risk premium associated with the emerging industry will decrease as the industry matures. In the model each investor type has a risk premium-which translates into a higher required rate of return - associated with investing in plants of each scale. The specific risk premium is based on overall industry experience at previous scale: the lower the level of experience, the higher the risk premium. As the industry grows, this risk premium diminishes.

Not shown in Figure B-5 is the role of venture capitalists in the investment decision. For venture capitalists, investment at demonstration scale occurs if the following conditions are met:

- Sufficient research has been conducted at pilot scale

- The industry size, as measured by its overall production capacity, is small

- The expected price of gasoline is greater than the anticipated price of btuequivalent ethanol. 
Accounting structure to track biofuels production facilities. The stock/flow structure used to track the number and conversion yield of biofuels production facilities is shown in Figure B-6.

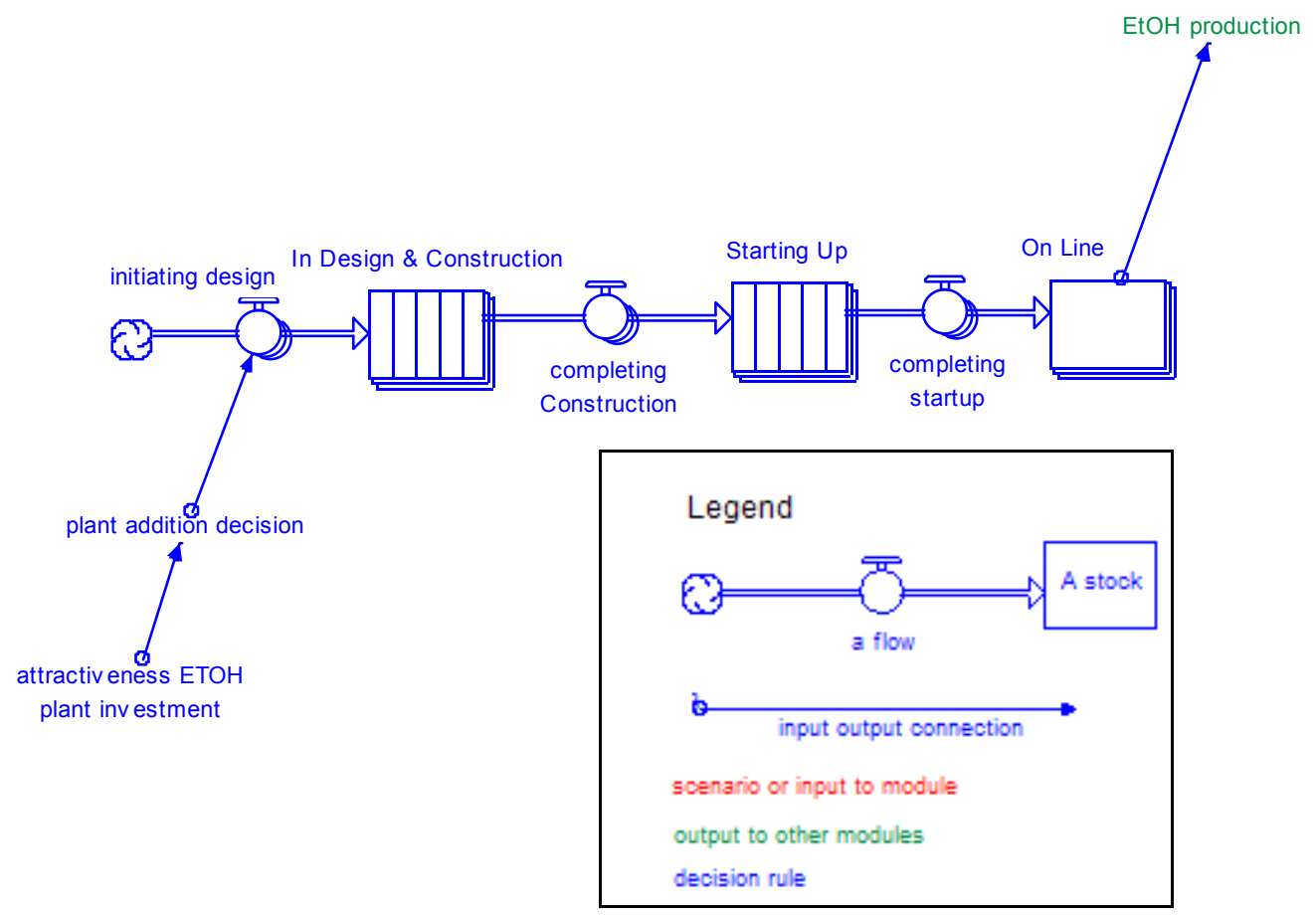

Figure B-6. Accounting Structure Used to Track Plants and Conversion Yields by Scale

This accounting structure is very straightforward. An array of plants by scale (demonstration, pioneer, full scale) moves through design \& construction, startup, and on-line phases of development. Design and construction time is assumed to be one year for demonstration-scale plants and two years for pioneer and full scale plants. Startup time is assumed to be one year for all plants. When a plant is added to the system, the prevailing industry conversion yield is "sampled" and thus works its way through the chain. Once plants are on line, conversion yields can increase through learning curve dynamics, discussed in the next section.

Pre-and Post-commercial $R \& D . R \& D$ is critical to the evolution of the cellulosic industry. By driving improvements in conversion yields and reducing risk, precommercial R\&D sets the stage for decisions to invest in demonstration, pioneer, and full scale conversion facilities. Once plants are in place, learning-curve dynamics lead to continuous improvement in performance of the industry. Figure B-7 shows a simplified representation of the core structure for these R\&D efforts. 


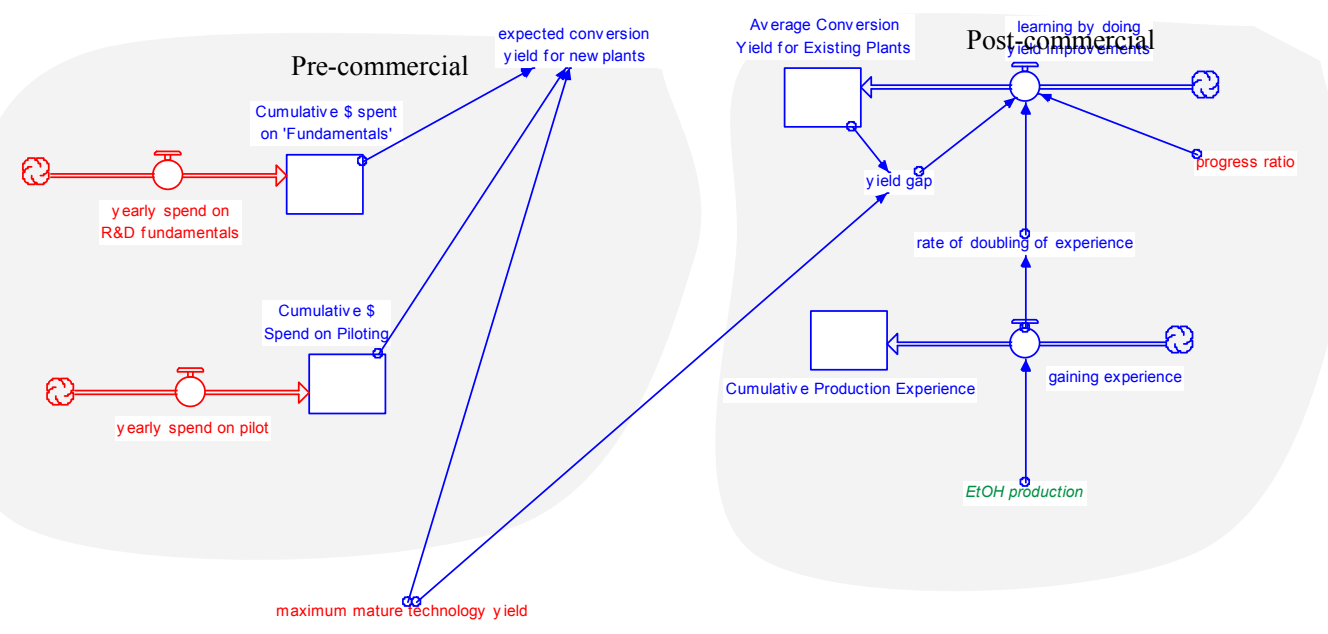

Figure B-7. Representation of Logic Surrounding Pre- and Post-Commercial R\&D

At the left of the figure is the structure that accounts for pre-commercial R\&D. Precommercial R\&D spending is allocated to "fundamentals" in the lab, or pilot-scale operations. The cumulative investment in these areas drives expected yield toward the (theoretical) maximum mature technology yield for a given technology pathways. In the model, three technology pathways are contemplated. It's possible for these pathways to exhibit different slopes and asymptotes in their yield curves. At any point in time, the new plant yield is a function of what has been invested to date in fundamentals and piloting.

At the right of the figure is a stylized view into the drivers of post-commercial R\&D. In the model, this form of R\&D is characterized as learning-by-doing and represented using learning curves. As with pre-commercial, the maximum mature technology yield sets a ceiling against which learning curves operate. The gap between this maximum and the average industry yield is eliminated in constant proportion to the rate of doubling of industry output.

\section{Biofuels Distribution Module}

No model structure exists around fuel transport from point of production to point of use. During development of the BSM, an assumption was made that fuel transportation would not limit the development of the biofuels industry. Subsequent (ongoing) development efforts include development of simple structure around fuel transport and distribution.

\section{Biofuels End Use Module}

The Biofuels End Use module drives the consumption of fuel ethanol. The purpose and approach of the model is threefold:

- Provide a physical basis for calculating the potential demand for ethanol as E10 and E85

- Provide a framework that accounts for the cumulative impact of initiatives around vehicle mix and efficiency 
- Provide self-contained laboratory for exploring impacts of alternate vehiclefocused policies and scenarios.

\section{Key Performance Indicators, Outputs, and Inputs}

Table B-4 summarizes key performance indicators, module outputs (to other modules), and module inputs (from other modules and from policy levers/scenarios). Taken as a whole, these indicators, outputs, and inputs give a sense for how this particular module interacts with the overall BSM structure.

Table B-4. KPIs, Outputs, and Inputs Associated with Biofuels End Use Module

\begin{tabular}{|c|c|c|c|}
\hline \multicolumn{4}{|c|}{ Key Performance Indicators: Biofuels End Use Module } \\
\hline Indicator & \multicolumn{3}{|l|}{ Notes } \\
\hline Gasoline price & \multicolumn{3}{|c|}{ At wholesale; driven by scenario variable } \\
\hline Total vehicles & \multicolumn{3}{|c|}{ Reflects cumulative impact of vehicle influx over time } \\
\hline $\begin{array}{l}\text { Total fuel } \\
\text { consumption/yr }\end{array}$ & \multicolumn{3}{|c|}{ In gasoline equivalent } \\
\hline Flex fuel vehicles & \multicolumn{3}{|c|}{ Cars and light trucks } \\
\hline Potential EtOH demand & \multicolumn{3}{|c|}{ Total demand, including E10 and E85 } \\
\hline $\begin{array}{l}\text { Fraction of E10 market } \\
\text { filled }\end{array}$ & \multicolumn{3}{|c|}{$\begin{array}{l}\text { E10 demand assumed to "fill" before E85 demand; assume that all EtOH } \\
\text { produced is sold }\end{array}$} \\
\hline $\begin{array}{l}\text { Fraction of E85 market } \\
\text { filled }\end{array}$ & \multicolumn{3}{|c|}{$\begin{array}{l}\text { E10 demand assumed to "fill" before E85 demand; assume that all EtOH } \\
\text { produced is sold }\end{array}$} \\
\hline EtOH supply & \multicolumn{3}{|c|}{$\begin{array}{l}\text { Generated by Biofuels Production module; assume that all EtOH produced is } \\
\text { sold until supply meets potential demand }\end{array}$} \\
\hline \multicolumn{4}{|c|}{ Outputs to Other Modules from Biofuels End Use Module } \\
\hline Output & Used In & How Used & Notes \\
\hline Potential EtOH demand & $\begin{array}{l}\text { Biofuels } \\
\text { Production }\end{array}$ & Input to plant addition logic & $\begin{array}{l}\text { As EtOH market reaches } \\
\text { saturation, growth in industry } \\
\text { slows. }\end{array}$ \\
\hline Gasoline price & $\begin{array}{l}\text { Biofuels } \\
\text { Production }\end{array}$ & Input to plant addition logic & $\begin{array}{l}\text { Attractiveness of new plant } \\
\text { additions is constrained by } \\
\text { relative price of EtOH and } \\
\text { gasoline (BTU equivalency } \\
\text { basis). }\end{array}$ \\
\hline \multicolumn{4}{|c|}{ Inputs to Biofuels End Use Module } \\
\hline Input & From & How Used & Notes \\
\hline EtOH supply & $\begin{array}{l}\text { Biofuels } \\
\text { Production }\end{array}$ & $\begin{array}{l}\text { Used to calculate "filling" of } \\
\text { E10, E85 markets }\end{array}$ & \\
\hline Oil price & Scenario & Drives logic of plant addition & \\
\hline $\begin{array}{l}\text { Distribution of incoming } \\
\text { vehicles }\end{array}$ & Scenario & $\begin{array}{l}\text { Distribution is applied to } \\
\text { yearly influx of new vehicles }\end{array}$ & $\begin{array}{l}\text { Mix of conventional gas, FFV, } \\
\text { other for cars, light trucks }\end{array}$ \\
\hline $\begin{array}{l}\text { Annual rate of growth in } \\
\text { vehicles }\end{array}$ & Scenario & $\begin{array}{l}\text { Used to drive growth in } \\
\text { number of vehicles over time }\end{array}$ & $\begin{array}{l}\text { Influx of vehicles includes } \\
\text { replacement of retirement }\end{array}$ \\
\hline $\begin{array}{l}\text { Efficiency of incoming } \\
\text { vehicles }\end{array}$ & Scenario & $\begin{array}{l}\text { Used to track overall average } \\
\text { efficiency of vehicles in use }\end{array}$ & $\begin{array}{l}\text { Efficiency tracked for } \\
\text { conventional gas, FFV, other } \\
\text { for cars, light trucks }\end{array}$ \\
\hline $\begin{array}{l}\text { Miles per vehicle per } \\
\text { year }\end{array}$ & Scenario & $\begin{array}{l}\text { Used to calculate overall fuel } \\
\text { demand; used to calculate } \\
\text { vehicle lifetime }\end{array}$ & $\begin{array}{l}\text { Miles per vehicle per year } \\
\text { tracked for conventional gas, } \\
\text { FFV, other for cars, light trucks }\end{array}$ \\
\hline $\begin{array}{l}\text { Avg miles per vehicle } \\
\text { before vehicle retires }\end{array}$ & Scenario & $\begin{array}{l}\text { Used to calculate vehicle } \\
\text { lifetime and retirements }\end{array}$ & \\
\hline
\end{tabular}




\section{Structure, Logic, and Decision Rules for the Biofuels End Use Module}

The Biofuels End Use module functions as a framework for accounting cumulative impacts of scenarios around vehicle type, distribution, and efficiency. This framework is then used to fuel demand. Figure B-9 presents a highly simplified representation of the accounting framework used in BSM Biofuels End Use module.

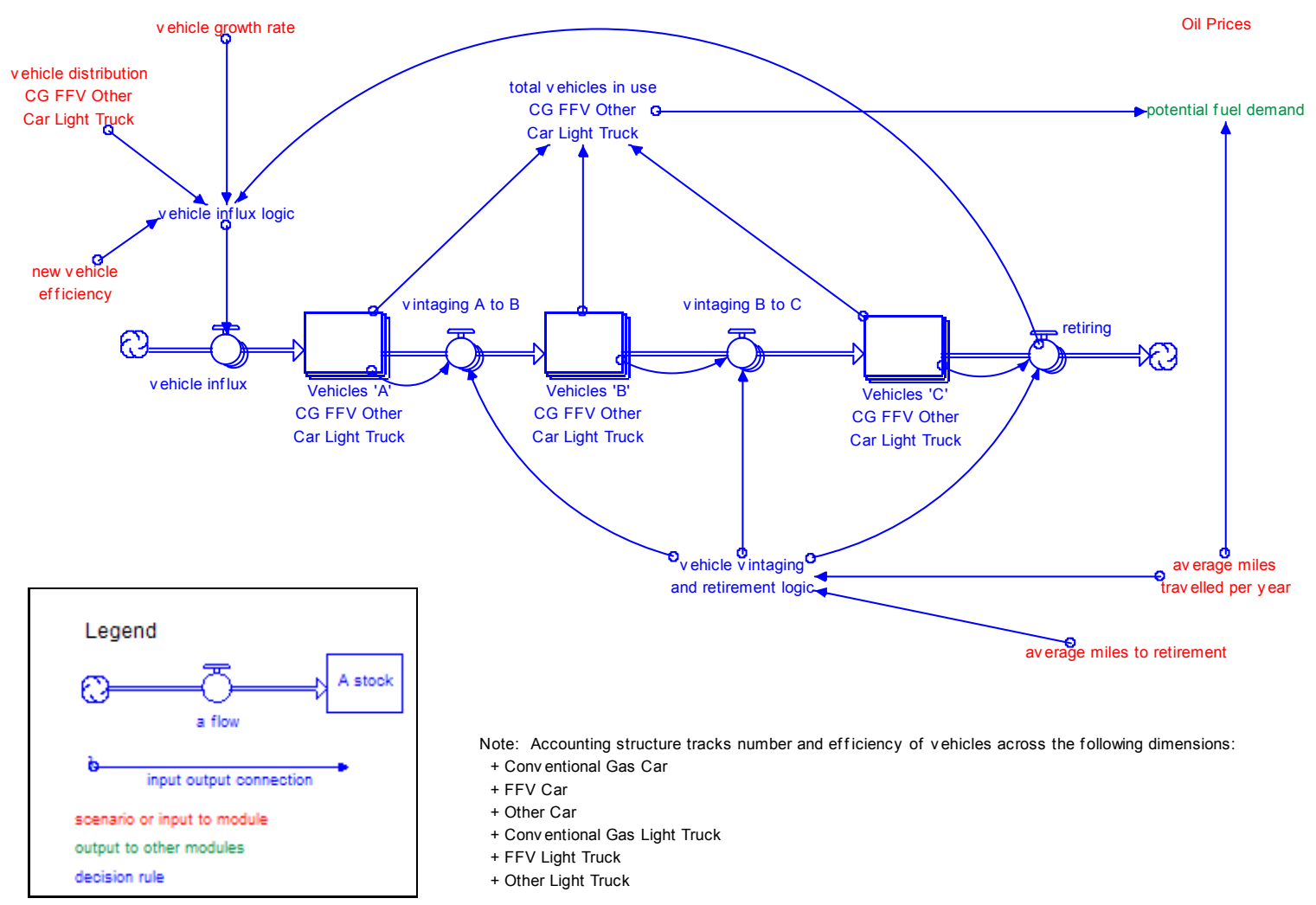

Figure B-8. Simplified Representation of Accounting Framework Used for BSM Biofuels End Use

Central to the accounting framework is the stock and flow structure that captures the vintaging of the vehicle population over time. Vehicles are divided into three vintage categories labeled "A", "B", and "C". New vehicles accumulate in category "A". As they vintage over time, they move into category " $\mathrm{B}$ " and category " $\mathrm{C}$ ". Retirements remove vehicles from the system.

The vintaging structure thus represents a third-order material delay. Movement through the structure is driven by vehicle vintaging and retirement logic, which in turn is developed based upon the scenario variables of average miles traveled per year and average miles driven per vehicle until retirement. Vehicle influx is driven by retirements (new vehicles replace retirements) as well as by scenario-driven assumptions around vehicle growth rates.

Within the model, this vintaging structure is used to track multiple attributes of the vehicle population. The current version of BSM tracks the distribution of vehicles 
between cars and light trucks. For each vehicle sub-population, the model captures the distribution of vehicles between conventional gasoline, flexible fuel, and other vehicles. Additionally, for each of the six sub-groups (vehicle type $x$ fuel type), BSM tracks average fuel efficiency. For the influx of new vehicles distributions between car and light truck and among fuel type are driven by scenario inputs. Similarly, fuel efficiency of each sub-group is driven by a scenario input.

As shown in Figure B-8 this structure is used to generate fuel demand over time. For the Biofuels End Use module, fuel demand comes in three forms: overall fuel demand, potential demand for E10, and potential demand for E85. These demand streams (overall and potential) are driven by the evolving attributes of vehicles in use, as well as by scenario-driven assumptions around miles traveled per year. Importantly, this physical reality sets a ceiling on what is physically achievable for the biofuels marketplace. An economic ceiling on what is achievable is set by the wholesale price for fuel. This latter concept is driven as a scenario input to the BSM. 


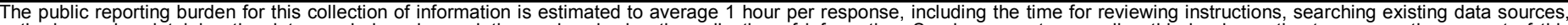

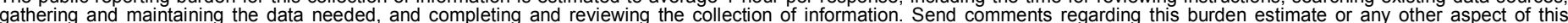

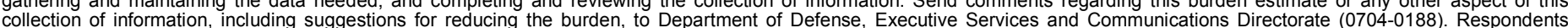

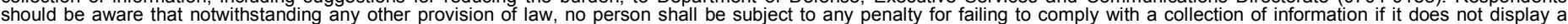

should be aware that notwithstanding

PLEASE DO NOT RETURN YOUR FORM TO THE ABOVE ORGANIZATION.

\begin{tabular}{l|l|l|l} 
1. REPORT DATE $(D D-M M-Y Y Y Y)$ & 2. REPORT TYPE & 3. DATES COVERED (FrOm - TO)
\end{tabular}

April 2008

Technical Report

4. TITLE AND SUBTITLE

Understanding the Growth of the Cellulosic Ethanol Industry

5a. CONTRACT NUMBER

DE-AC36-99-G010337

5b. GRANT NUMBER

5c. PROGRAM ELEMENT NUMBER

6. AUTHOR(S)

D. Sandor, R. Wallace, and S. Peterson

5d. PROJECT NUMBER

NREL/TP-150-42120

5e. TASK NUMBER

BZ07.1005

5f. WORK UNIT NUMBER
7. PERFORMING ORGANIZATION NAME(S) AND ADDRESS(ES)

National Renewable Energy Laboratory

1617 Cole Blvd.

Golden, CO 80401-3393
8. PERFORMING ORGANIZATION REPORT NUMBER

NREL/TP-150-42120

9. SPONSORING/MONITORING AGENCY NAME(S) AND ADDRESS(ES)

10. SPONSOR/MONITOR'S ACRONYM(S) NREL

11. SPONSORING/MONITORING AGENCY REPORT NUMBER

12. DISTRIBUTION AVAILABILITY STATEMENT

National Technical Information Service

U.S. Department of Commerce

5285 Port Royal Road

Springfield, VA 22161

13. SUPPLEMENTARY NOTES

14. ABSTRACT (Maximum 200 Words)

This report identifies, outlines, and documents a set of plausible scenarios for producing significant quantities of lignocellulosic ethanol in 2017 . These scenarios can provide guidance for setting government policy and targeting government investment to the areas with greatest potential impact.

15. SUBJECT TERMS

cellulosic ethanol; lignocellulosic; feedstock; renewable fuel standard; RFS; grower payment; STELLA; BSM

\begin{tabular}{l}
\hline \multicolumn{3}{|l|}{ 16. SECURITY CLASSIFICATION OF: } \\
\hline \begin{tabular}{l|l|l|} 
a. REPORT & b. ABSTRACT & c. THIS PAGE \\
Unclassified & Unclassified & Unclassified \\
& & \\
\hline
\end{tabular} \\
\hline
\end{tabular}

\begin{tabular}{|c|c|}
\hline $\begin{array}{l}\text { 17. LIMITATION } \\
\text { OF ABSTRACT }\end{array}$ & $\begin{array}{l}\text { 18. NUMBER } \\
\text { OF PAGES }\end{array}$ \\
\hline UL & \\
\hline
\end{tabular}

19a. NAME OF RESPONSIBLE PERSON

19b. TELEPHONE NUMBER (Include area code) 